\title{
Effective Judicial Protection and Mutual Recognition in the European Administrative Space
}

\author{
Luis Arroyo Jiménez ${ }^{\star}$ (1) \\ Faculty of Law and Social Sciences, University of Castilla-La Mancha, Ciudad Real, Spain \\ Corresponding author: Luis Arroyo Jiménez, Email: luis.arroyo@uclm.es
}

(Received 22 March 2021; accepted 11 April 2021)

\begin{abstract}
The right to effective judicial protection is driving to a significant evolution of EU administrative law, especially in view of the multijurisdictional nature of the European administrative structure. This Article focuses on gaps in judicial protection arising from mutual recognition in transnational interactions between the administrative authorities of the EU's Member States. It first sets the ground by examining the ingredients of the equation: The fundamental right to effective judicial protection, the concept and forms of mutual recognition, and the notion of European administrative space. Next, this Article assesses the judicial protection that private parties can obtain from national courts in these transnational scenarios. Procedure, substance, and deference are separately explored here, in order to draw out blind spots and deficiencies, as well as to suggest possible solutions to address at least some of them. This Article ends with a brief summary of the main findings.
\end{abstract}

Keywords: Mutual recognition; Judicial protection; Effectiveness; Administrative law; Transnational administration

\section{A. Introduction}

Challenges of judicial protection in the European administrative space are many and diverse. Some arise from the fact that EU primary law is undergoing a complex evolution in terms of how judicial control must be carried out at both the supranational and national levels. The current EU constitutional framework of judicial protection is composed of various partially overlapping legal norms with somewhat particular contents, structures, and purposes. This framework also essentially rests on the distribution of exclusive jurisdiction between the supranational and the national courts, as well as a further distribution between the national courts themselves. ${ }^{1}$ Although this architecture functions reasonably well in areas of strict decentralized enforcement, it inevitably creates uncertainties when EU law is enforced through shared or integrated

${ }^{\star}$ Professor of Administrative Law. Jean Monnet Chair in European Administrative Law in Global Perspective. University of Castilla-La Mancha. This Article has been written with the support of a grant of the Spanish National Research Plan (PGC2018-101476-B-I00).

${ }^{1}$ Herwig C.H. Hofmann \& Morgane Tidghi, Rights and Remedies in Implementation of EU Policies by Multi-Jurisdictional Networks, 20 EUR. PUB. L. 147, 154 (2014).

(c) The Author(s) 2021. Published by Cambridge University Press on behalf of the German Law Journal. This is an Open Access article, distributed under the terms of the Creative Commons Attribution licence (http://creativecommons.org/licenses/by/4.0/), which permits unrestricted re-use, distribution, and reproduction in any medium, provided the original work is properly cited. 
organizational and procedural structures. These difficulties can arise from interactions occurring in both the vertical and horizontal senses. Vertical composite procedures give rise to certain peculiar gaps in terms of judicial protection that are considered in the case law of the Court of Justice of the European Union (CJEU), as well as in academic doctrine. ${ }^{2}$

Less attention has been paid, however, to judicial control blind spots arising in horizontal interactions. While some of those blind spots result from secondary legislation that designs administrative cooperation mechanisms ${ }^{3}$ and composite decision-making procedures, ${ }^{4}$ others arise from primary or secondary EU law creating mutual recognition obligations and therefore granting transnational effects to measures taken by national authorities. ${ }^{5}$ Specifically, this Article focuses on gaps in judicial protection arising from mutual recognition in transnational interactions between the EU's Member States. It aims at exploring, mapping, and classifying the lack of effective judicial protection in these particular scenarios, and suggests possible solutions to address at least some of those gaps.

Accordingly, the structure of the Article is as follows. First, Section B examines the ingredients of the equation: The fundamental right to effective judicial protection, the concept and forms of mutual recognition, and the notion of European administrative space. Next, Section C looks at the judicial protection that private parties can obtain from national courts in these transnational scenarios, drawing out blind spots and deficiencies, as well as looking for possible justifications or solutions. Finally, Section D sketches out the main conclusions of this Article.

\section{B. Drawing the Map}

\section{Effective Judicial Protection}

In order to find gaps in judicial control arising in transnational interactions, it is necessary, as a preliminary matter, to refer to the sources, content, structure, and context in which the EU law principle of effective judicial protection applies.

\section{Sources}

The principle of effective judicial protection has been incorporated into EU law in various forms. First, effective judicial protection has been proclaimed by the Court of Justice as a general principle of Community law which underlies the constitutional traditions that are common to the Member States, as they are reflected in Articles 6 and 13 of the European Convention on Human Rights (ECHR). ${ }^{6}$ Second, there is a partial overlap between the "general principle of effective judicial

\footnotetext{
${ }^{2}$ Sergio Alonso de León, Composite Administrative Procedures in the European Union 251-318 (2017); Filipe Brito Bastos, The Borelli Doctrine Revisited: Three Issues of Coherence in a Landmark Ruling for EU Administrative Justice, 8 Rev. Eur. Admin. L. 269 (2015); Filipe Brito Bastos, Derivative Illegality in European Composite Administrative Procedures, 55 Common Mкт. L. Rev. 101 (2018); Filipe Brito Bastos, Judicial Review of Composite Administrative Procedures in the Single Supervisory Mechanism: Berlusconi, 56 CoMmon MKT. L. Rev. 1355-78 (2019); Mariolina Eliantonio, Judicial Review in an Integrated Administration: The Case of “Composite Procedures," 7 Rev. Eur. AdmIN. L. 65 (2014); Joseba Fernández Gaztea, A Jurisdiction of Jurisdictions 12 Rev. EUR. Admin. L. 9 (2019); Herwig C.H. Hofmann, Multi-Jurisdictional Composite Procedures, 6-18 (Univ. of Luxembourg, Working Paper No. 003-2019, 2019).

${ }^{3}$ Herwig C.H. Hofmann, The Right to an Effective Remedy and to a Fair Trial-Article 47 of the Charter and the Member States, in The EU Charter of Fundamental Rights 1227-28 (Angela Ward ed., 2d ed. 2015); Hofmann, supra note 2, at 19-21.

${ }^{4}$ Herwig C.H. Hofmann, Gerard C. Rowe \& Alexander H. Türk, Administrative Law and Policy of the EUROPEAN UNION 408 (2011); Luis Arroyo Jiménez \& Mariolina Eliantonio, Masks, Gloves, Exports Licences and Composite Procedures: Implementing Regulation 2020/402 and the Limelight of Accountability, 11 EUR. J. RISK REG. 382-89 (2020).

${ }^{5}$ Herwig C.H. Hofmann, Composite Decision Making Procedures in EU Administrative Law, in LEGAL CHALLENGES IN EU Administrative LaW 151-52 (Herwig C.H. Hofmann \& Alexander H. Türk eds., 2009).

${ }^{6}$ ECJ, Case C-222/84, Johnston v. Chief Constable of the Royal Ulster Constabulary, ECLI:EU:C:1986:206 (May 15, 1986), para. 18, http://curia.europa.eu/juris/liste.jsf?language=en\&jur=C,T,F\&num=c-222/84\&td=ALL; ECJ, Case C-222/86,
} 
protection" and the older "principle of effectiveness of EU law," the judicial application of EU law by national courts. ${ }^{8}$ Third, the Treaty of Lisbon has provided for two other constitutional foundations of the principle of effective judicial protection. On the one hand, Article 19 of the Treaty on European Union (TEU) states that it is the task of the CJEU to ensure "that in the interpretation and application of the Treaties the law is observed," as well as that "Member States shall provide remedies sufficient to ensure effective legal protection in the fields covered by Union law." 9 On the other hand, Article 47 of the Charter of Fundamental Rights of the EU proclaims the fundamental right to an effective remedy and to a fair trial. ${ }^{10}$ It is, finally, important to bear in mind that this principle has both a subjective and an objective dimension, ${ }^{11}$ as well as that it is conceived of by both the CJEU ${ }^{12}$ and the academic doctrine ${ }^{13}$ as being one of the most distinctive requirements of the rule of law, enshrined as an EU value in Article 2 TEU.

Since 2009, the CJEU has seemed to deal with the principle from the perspective of Articles 19 TEU and 47 of the Charter more often, instead of the general principle of effective judicial protection, as it arises from the constitutional traditions common to the Member States. Accordingly, the ECHR is shifting away from being a privileged source in order to elucidate what those common traditions actually are, towards being a privileged source of interpretation of the provisions of the Charter. ${ }^{14}$ This is the constitutional framework that slowly seems to be gaining more weight in the Court of Justice's case law on effective judicial protection.

\section{Content}

The content of the right of effective judicial protection comprises a number of distinct building blocks, such as the right of access to court, the rights of defense, the right to a fair trial, the right to

UNECTEF v. Heylens, ECLI:EU:C:1987:442, (Oct. 15, 1987), para. 15, http://curia.europa.eu/juris/liste.jsf?language=en\& num $=\mathrm{C}-222 / 86$.

${ }^{7}$ ECJ, Case C-33/76, Rewe-Zentralfinanz v. Landwirtschaftskammer fur das Saarland, ECLI:EU:C:1976:188 (Dec. 16, 1976), para. 5, http://curia.europa.eu/juris/liste.jsf?language=en\&num=C-33/76.

${ }^{8}$ See generally Sacha Prechal \& Rob Widdershoven, Redefining the Relationship Between 'Rewe-Effectiveness' and Effective Judicial Protection, 4 Rev. Eur. Admin. L. 31-51 (2011); Jasper Krommendijk, Is There Light on the Horizon? The Distinction Between "Rewe-Effectiveness" and the Principle of Effective Judicial Protection in Article 47 of the Charter After Orizzonte, 53 Common Mкт. L. Rev. 1395 (2016); Rob Widdershoven, National Procedural Autonomy and General EU Law Limits 12 ReV. Eur. AdMIN. L. 5-34 (2019).

${ }^{9}$ Treaty on European Union art. 19, Feb. 7, 1992, 1992 O.J. (C 224) 1 [hereinafter TEU].

${ }^{10}$ Charter of Fundamental Rights of the European Union art. 47, Dec. 18, 2000, 2000 O.J. (C 364) 1 [hereinafter the Charter].

${ }^{11}$ Sacha Prechal \& Rob Widdershoven, Principle of Effective Judicial Protection, in CONTROLLING EU AgENCIES: THE RULE of Law in a Multi-Jurisdictional Legal Order 80, 82 (Miroslava Scholten \& Alex Brenninkmeijer eds., 2020); Matteo Bonelli, Effective Judicial Protection in EU Law: An Evolving Principle of a Constitutional Nature, 12 REV. EUR. ADMIN. L. 35, 37 (2019).

${ }^{12}$ ECJ, Case C-294/83, Parti ecologiste “Les Verts” v. European Parliament, ECLI:EU:C:1986:166 (Apr. 23, 1986), para 23, http://curia.europa.eu/juris/liste.jsf?language=en\&jur=C,T,F\&num=294/83\&td=ALL; ECJ, Joined Cases C-402 \& 415/05, Kadi \& Al Barakaat Int'l Found. v. Counsel of the European Union and the Comm'n of the European Cmtys., ECLI:EU: C:2008:461, Judgement of 3 Sept. 2008, paras. 281 \& 316, http://curia.europa.eu/juris/liste.jsf?num=C-402/05; ECJ, Case C-64/16, Associação Sindical dos Juízes Portugueses v. Tribunal de Contas, ECLI:EU:C:2018:117 (Feb. 27, 2018), para. 36, http://curia.europa.eu/juris/liste.jsf?num=C-64/16; ECJ, Case C-619/18, Comm'n. v. Poland, ECLI:EU:C:2019:531 (June 24, 2019), para. 58, http://curia.europa.eu/juris/liste.jsf?num=C-619/18.

${ }^{13}$ Prechal \& Widdershoven, supra note 8, at 47; Prechal \& Widdershoven, supra note 9, at 83; Filipe Brito Bastos, An Administrative Crack in the EU's Rule of Law: Composite Decision-Making and Nonjusticiable National Law, 16 EuR. Const. L. Rev. 1, 18 (2020).

${ }^{14}$ Charter of Fundamental Rights of the European Union, art. 52(3), 2012 O.J. (C 326) 391; ECJ, Case C-279/09, DEB Deutsche Energiehandels-und Beratungsgesellschaft mbH v. Bundesrepublik Deutschland, ECLI:EU:C:2010:811 (Dec. 22, 2010), http://curia.europa.eu/juris/liste.jsf?num=C-279/09; ECJ, Case C-64/16, Associação Sindical dos Juízes Portugueses v. Tribunal de Contas, ECLI:EU:C:2018:117 (Feb. 27, 2018), http://curia.europa.eu/juris/liste.jsf?num=C-64/16; ECJ, Case C-619/18, Comm'n. v. Poland, ECLI:EU:C:2019:531 (June 24, 2019), para. 58, http://curia.europa.eu/juris/liste.jsf?num= C-619/18. 
an independent court, the right to comprehensive judicial review, and so on. ${ }^{15}$ Articles 19 TEU and 47 of the Charter, therefore, enshrine a set of constitutional norms. The Court of Justice's case law of the last decade has been fertile in terms of interpreting and construing many of these building blocks. Two of them are of particular interest in terms of mutual recognition and will be taken into consideration here.

The first is the right of access to a court, which brings about a number of issues that question whether and to what extent procedural law guarantees effective judicial protection. ${ }^{16}$ Both EU and national procedural law can have an effect on this right of access from at least three different perspectives: One relates to the rules that allocate jurisdiction to courts ${ }^{17}$ and establish time limits or other conditions to bring actions ${ }^{18}$; another is that of rules defining the acts that can be challenged before a court ${ }^{19}$; and the final relates to rules that impose standing requirements for the action to be admissible. ${ }^{20}$ Therefore, judicial protection can ceteris paribus be more or less effective depending on the scope of access to court that derives from these rules.

The second is the right to comprehensive judicial review, namely examination of all facts and legal issues that might be relevant to settle the dispute. Academic commentary has pointed out that this requirement of "sufficient jurisdiction" can be grounded on a systematic interpretation of Article 47 of the Charter, in view of Articles 6(1) and 13 of the ECHR. ${ }^{21}$ The Court of Justice has ruled that Article 47 of the Charter demands that the Court has "jurisdiction to consider all the relevant issues." 22 More precisely, the Court "must have power to consider all the questions of fact and law that are relevant to the case before it." ${ }^{23}$ This right can also be restricted by procedural law: Rules establishing limitations on the review of both fact and law before certain courts-often supreme and constitutional courts, or in particular types of appeal-cassation, revision, amparo, and so $\mathrm{on}^{24}$; rules and judicial practices concerning different standards of review ${ }^{25}$; and rules that

\footnotetext{
${ }^{15}$ Prechal \& Widdershoven, supra note 9, at 82-86; Brito Bastos, supra note 11 , at 18-21.

${ }^{16}$ Prechal \& Widdershoven, supra note 9, at 84-85.

${ }^{17}$ ECJ, Case C-72/15, PJSC Rosneft Oil Co. v. Her Majesty's Treasury, ECLI:EU:C:2017:236 (Mar. 28, 2017), para. 74, http:// curia.europa.eu/juris/liste.jsf?num $=\mathrm{C}-72 / 15$.

${ }^{18}$ Prechal \& Widdershoven, supra note 8 , at $47-48$.

${ }^{19}$ ECJ, Case C-97/91, Oleificio Borelli SpA v. Comm'n of the European Communities, ECLI:EU:C:1992:491 (Dec. 3, 1992), http://curia.europa.eu/juris/liste.jsf?language=en\&num=c-97/91\&td=ALL; ECJ, Case C-562/12, Liivimaa Lihaveis MTÜ v. Eesti-Läti programmi 2007-2013 Seirekomitee, ECLI:EU:C:2014:2229 (Sept. 17, 2014), http://curia.europa.eu/juris/liste.jsf? language $=$ en $\&$ num $=\mathrm{C}-562 / 12$.

${ }^{20}$ ECJ, Case C-174/02, Streekgewest Westelijk Noord-Brabant v Staatssecretaris van Financiën, ECLI:EU:C:2005:10 (Jan. 13, 2005), http://curia.europa.eu/juris/liste.jsf?language=en\&jur=C,T,F\&num =C-174/02\&td=ALL.

${ }^{21}$ Terra Woningen B.V. v. the Netherlands, 24 Eur. H.R. Rep. 456 (1997), http://hudoc.echr.coe.int/app/conversion/pdf/? library=ECHR\&id=001-58082\&filename=001-58082.pdf; Prechal \& Widdershoven, supra note 8, at 48; Brito Bastos, supra note 11 , at 19 .

${ }^{22}$ ECJ, Case C-682/15, Berlioz Inv. Fund SA v. Directeur de l'administration des contributions directes, ECLI:EU: C:2017:373 (May 16, 2017), para. 55, http://curia.europa.eu/juris/liste.jsf?num=C-682/15; ECJ, Case C-403/16, Soufiane El Hassani v. Minister Spraw Zagranicznych, ECLI:EU:C:2017:960 (Dec. 13, 2017), para. 39, http://curia.europa.eu/juris/liste. jsf?language $=$ en $\&$ jur $=\mathrm{C}, \mathrm{T}, \mathrm{F} \&$ num $=\mathrm{c}-403 / 16$.

${ }^{23}$ ECJ, Case C-199/11, Europese Gemeenschap v. Otis and others, ECLI:EU:C:2012:684 (Nov. 6, 2012) para. 49, http://curia. europa.eu/juris/liste.jsf?num=C-199/11; ECJ, Case C-300/14, Imtech Marine Belgium NV v. Radio Hellenic SA, ECLI:EU: C:2015:825 (Dec. 17, 2015) para. 38, http://curia.europa.eu/juris/liste.jsf?language=en\&num=C-300/14. See also the Opinion of AG Bobek at para. 103, Case C-89/17, Secretary of State for the Home Department v. Rozanne Banger (July 12, 2018), http://curia.europa.eu/juris/liste.jsf?language=en\&td=ALL\&num=C-89/17.

${ }^{24}$ See a brief comparative overview in Rob Widdershoven, Appellate Proceedings, in JUdiCial Review of Administrative ACTION 692-704 (Chris Backes \& Mariolina Eliantonio eds., 2020).

${ }^{25}$ See generally PaUl Craig, EU Administrative LAW 436-83 (3d ed. 2018); Rob Widdershoven, The European Court of Justice and the Standard of Judicial Review, in Judicial Review of Administrative DisCretion In THE AdMINISTRATIVE STAте 39-62 (Jurgen de Poorter, Ernst Hirsch Ballin, \& Saskia Lavrijssen eds., 2019); Prechal \& Widdershoven, note 9 , at $85-86$.
} 
define courts' prerogatives and remedies that can be granted. ${ }^{26}$ From this perspective, judicial protection can ceteris paribus be more or less effective in view of the intensity of judicial review that is brought about by these rules.

\section{Structure}

Another issue altogether is that of the structure of the different components of the right to effective judicial protection, or in other words, how those components behave when they collide with other rights, principles, or interests. According to a widespread view, fundamental rights norms may operate both as rules - in a binary, or all-or-nothing manner, ${ }^{27}$ and as principles, or mandates of optimization-or as norms that require the achievement of a certain outcome to the greatest degree that is factually and legally possible, and that therefore apply gradually. ${ }^{28}$ Whereas in the first scenario fundamental rights are indefeasible legal norms, in the second, they can be defeated by competing legal reasons. This distinction reflects how the right functions vis-à-vis its possible limitations. Both the right to access to justice and the right to comprehensive judicial review of all the relevant facts and legal issues are usually subject to limitations established by EU and national procedural law. Under Article 52(1) of the Charter, the admissibility of these limitations is conditioned by certain requirements or limits. The various components of the right to effective judicial protection, as well as the restrictions imposed thereon, can be rationalized under a mixed model of rules and principles.

The rights included in the content of the right to effective judicial protection sometimes function as principles, in that they prima facie require the most extensive and intensive judicial protection that is factually and legally possible. The very notion of effectiveness reflects this gradual nature of the right. This requirement, however, may collide with factual limits, as well as with the requirements brought about by competing legal interests. ${ }^{29}$ Rules that limit the right of access to a court by defining certain standing or reviewability requirements do restrict the scope of the right in view of what is factually possible-judicial protection is a public service, the provision of which is dependent on financial resources, as well as on other constitutional reasons-for example territoriality, res judicata, legal certainty, and so on. ${ }^{30}$ Likewise, rules and practices that limit judicial review to certain factual or legal questions, as well as those defining more or less deferential standards of review, therefore restricting the intensity of the right, might be justified by virtue of other controlling principles: Autonomy, uniformity, democracy, epistemic justice, and so on. ${ }^{31}$ According to Article 52(1) of the Charter, and as far as substantive review is concerned, these rules and practices are valid as long as they: (i) Pursue objectives of general interest recognized by the EU or the need to protect the rights and freedoms of others, (ii) satisfy the principle of proportionality, and (iii) respect the essence of the right. ${ }^{32}$ The part of the content of

\footnotetext{
${ }^{26}$ See generally CraIG, supra note 23, at 722-94. See ECJ, Case C-432/05, Unibet Ltd. v. Justitiekanslern, ECLI:EU: C:2007:163 (Mar. 13, 2007), para. 42, http://curia.europa.eu/juris/liste.jsf?num=C-432/05 (stressing the connection with effective judicial protection); ECJ, Case C-752/18, Deutsche Umwelthilfe eV v. Freistaat Bayern, ECLI:EU:C:2019:1114 (Dec. 19, 2019), paras. 34-39, http://curia.europa.eu/juris/liste.jsf?num $=\mathrm{C}-752 / 18$.

${ }^{27}$ Ronald Dworkin, Taking Rights Seriously 25-26 (1977).

${ }^{28}$ Robert Alexy \& Julian Rivers, A Theory of Constitutional Rights 69-86 (1st ed. 2010).

${ }^{29}$ Prechal \& Widdershoven, supra note 8, at 42-43; Brito Bastos, supra note 11, at 25-26.

${ }^{30}$ See, e.g., ECJ, Case C-620/17, Hochtief Solutions AG Magyarországi Fióktelepe v. Fővárosi Törvényszék, ECLI:EU: C:2019:630 (July 29, 2019), para. 54, http://curia.europa.eu/juris/liste.jsf?language=en\&num=C-620/17 (stating that the principle of res judicata impedes the review of definitive decisions in order to protect the stability of the law and of legal relations).

${ }^{31}$ See, e.g., ECJ, Case C-11/70, Internationale Handelsgesellschaft mbH v. Einfuhr- und Vorratsstelle für Getreide und Futtermittel, ECLI:EU:C:1970:114 (Dec. 17, 1970), para. 3, http://curia.europa.eu/juris/liste.jsf?language=en,T,F\&num=1170 (stating that the validity of EU acts is not dependent on national law); ECJ, Case C-50/00 P, Unión de Pequeños Agricultores v. Council, ECLI:EU:C:2002:462 (July 25, 2002), para. 43, http://curia.europa.eu/juris/liste.jsf?language=en\& num $=\mathrm{C}-50 / 00$ (stating that the ECJ has no competence to apply national law).

${ }^{32}$ The Charter art. $52(1)$.
} 
the right to effective judicial protection that can be restricted under these conditions functions according to a model of principles.

In turn, the right operates as a rule in three other situations. First, in those cases where the prima facie content of the right does not collide with opposing factual or legal restrictionswhether they arise from objectives of general interest, or from the rights and freedoms of others. Second, even when it does oppose other rights, principles, or interests that could justify a limitation, procedural law might grant prevalence to the right to effective judicial protection, the authority of which would therefore not be defeated. For example, access to a court can either be limited to those whose subjective rights are affected, such as in Germany or Austria, or granted to those with a direct interest, as in France, ${ }^{33}$ or even to those with an indirect interest, as in Spain. ${ }^{34}$ And third, the right also applies in an all-or-nothing manner with regard to those contents that cannot be restricted without infringing the said conditions-especially proportionality and essence, such as the existence of a remedy of judicial nature against decisions taken by both national and EU authorities. One example is the prohibition of rules granting immunity from jurisdiction to certain categories of legal acts of public authorities. ${ }^{35}$ In these three scenarios, the right to effective judicial protection functions under a model of rules as long as their contents are indefeasible. Accordingly, the right to effective judicial protection would here not apply gradually, but in a complete manner.

In other words, this fundamental right can work gradually-because it demands the most effective judicial protection that is possible to be provided, but also in a binary way-as long as procedural law specifies the definitively protected content of the right, which in turn must satisfy a minimum level of protection arising from the "limits to the limitations" provided for in Article 52(1) of the Charter. ${ }^{36}$ The doctrinal challenge that Articles 19 TEU and 47 of the Charter currently pose is more clearly distinguishing between the right's contents that behave in one way and in the other.

\section{Context}

A final issue that must be tackled here relates to the context in which the right to effective judicial protection applies. It is readily apparent that Article 47 of the Charter applies to the institutions, bodies, offices, and agencies of the EU, as well as to Member States "when they are implementing EU law." ${ }^{37}$ However, Article 19 TEU contains a slightly different formula: "Member States shall provide remedies sufficient to ensure effective legal protection in the fields covered by Union law." ${ }^{38}$ Recent case law of the Court of Justice has established that the expression "fields covered by Union law" must be construed "irrespective of whether the Member States are implementing Union law, within the meaning of Article 51(1) of the Charter." 39 Article 19 TEU applies, therefore, to any judicial body that can potentially be called to interpret and apply EU law. ${ }^{40}$ The principle applies on both levels of judicial protection: Before EU and Member States' courts. However, the right does not operate in a detached and disconnected manner for them. The right to effective judicial protection must be interpreted in view of the multijurisdictional nature of the judicial union. In

\footnotetext{
${ }^{33}$ Prechal \& Widdershoven, supra note 9 at 84. See MARIOLINA ELIANTONIO, STANDING UP FOR YOUR RIGHT(S) IN EUROPE: A Comparative Study on Legal Standing (Locus Standi) before the EU and Member States' Courts 116 (Chris W. Backes, Mariolina Eliantonio, C.H. van Rhee \& Taru Spronken eds., 2013).

${ }^{34}$ CONSTITUCiÓn EsPAñola art. 24.1.

${ }^{35}$ ECJ, Joined Cases C-402 \& 415/05, Kadi \& Al Barakaat Int'l Found. v. Counsel of the European Union and the Comm'n of the European Cmtys., ECLI:EU:C:2008:461, Judgement of 3 Sept. 2008, paras. 281 \& 316, http://curia.europa.eu/juris/liste.jsf? num $=$ C-402/05.

${ }^{36}$ The Charter art. 52(1).

${ }^{37}$ The Charter art. 51(1).

${ }^{38}$ TEU art. 19.

${ }^{39}$ ECJ, Case C-64/16, Associação Sindical dos Juízes Portugueses v. Tribunal de Contas, ECLI:EU:C:2018:117 (Feb. 27, 2018), para. 29, http://curia.europa.eu/juris/liste.jsf?num=C-64/16.

${ }^{40}$ Bonelli, supra note 9 , at 48 .
} 
particular, both supranational and national procedural law and practice have to be assessed in view of their global impact on the composite legal order-not exclusively from the perspective of their behavior within one of its layers, whether that layer is the EU or the domestic one.

This is not only a normative point made in view of the composite nature of the EU legal order but also a positive description of the approach of the Court of Justice to this question. Therefore, in Les Verts, the Court declared that the Treaty of the European Economic Community established a complete system of legal remedies and procedures designed to permit the Court of Justice to review the legality of measures adopted by the institutions. ${ }^{41}$ The Court concluded this as long as direct actions against national implementing measures before national courts could give rise to the latter making references for preliminary rulings on the validity of secondary law that might not be possible to challenge in the form of annulment actions before the CJEU. ${ }^{42}$ Likewise, the need to guarantee effective judicial protection led the Court in Borelli to declare that national courts must review certain national preparatory acts as if they were final decisions, because they could not be reviewed before the CJEU. ${ }^{43}$ Finally, in Berlioz, the Court of Justice stated that, when reviewing the action of domestic authorities aimed at enforcing a foreign act, Article 47 of the Charter requires that national courts must have jurisdiction to review the legality of the latter. ${ }^{44}$ In all those cases, the Court of Justice assessed the requirements of the rule of law and of the right to effective judicial protection in view of the impact of the EU or national procedural rule at stake on the whole EU multi-jurisdictional system, from a both vertical and horizontal perspective. Rules and principles enshrined in Article 47 of the Charter, therefore, must also be interpreted and construed taking into account the multijurisdictional nature of the EU.

\section{Mutual Recognition}

\section{Concept}

Mutual recognition is the second element of the equation this Article is dealing with. Mutual recognition has been defined in different manners and as having various scopes of application. This has given rise to a number of ways in which this regulatory arrangement may be understood, from both a formal perspective, focused on its legal effects, ${ }^{45}$ and a functional perspective, focused on its political or regulatory purposes. ${ }^{46}$ I will adopt here a very wide notion: Mutual recognition is a regulatory arrangement under which the administrative or judicial authorities of one Member State must give legal effects within their territory to rules or acts passed by the legislative, administrative, or judicial authorities of another Member State. Mutual recognition, therefore, is the content of a legal obligation incumbent on "host" authorities, namely (i) to accept that a rule or act passed by "home" authorities and aimed at having legal effects in the territory of origin, also has legal effect in the territory of destination, and (ii) consequently, to refrain from applying their own law to a case, to the extent that doing so might impede (i). Accordingly, mutual recognition is a regulatory policy that rests on a legal norm or agreement imposing such a legal obligation, the immediate consequence of which is that rules and acts passed by the authorities of

\footnotetext{
${ }^{41}$ Parti ecologiste "Les Verts", Case 294/83 at para. 23.

${ }^{42}$ Parti ecologiste "Les Verts", Case 294/83 at para 23; Unión de Pequeños Agricultores, Case C-50/00 P at para. 40, ECJ, Case C-583/11 P, Inuit Tapiriit Kanatami v. Parliament and Council, ECLI:EU:C:2013:625 (Oct. 3, 2013), para. 92, http://curia. europa.eu/juris/liste.jsf?num $=\mathrm{C}-583 / 11$ \&language $=\mathrm{EN}$; ECJ, Case C-384/16 P, European Union Copper Task Force v. Commission, ECLI:EU:C:2018:176 (Mar. 3, 2018), paras. 111-17, http://curia.europa.eu/juris/liste.jsf?num=C-384/16\& language $=\mathrm{EN}$.

${ }^{43}$ ECJ, Case C-97/91, Oleificio Borelli SpA v. Comm'n of the European Communities, ECLI:EU:C:1992:491 (Dec. 3, 1992), paras. 13-14, http://curia.europa.eu/juris/liste.jsf?language $=e n \& n u m=c-97 / 91 \& t d=A L L$.

${ }^{44}$ Berlioz, Case C-682/15 at paras. 55-56, 84-85.

${ }^{45}$ Christine Janssens, The Principle of Mutual Recognition in EU Law 4-5, 123-24 (2015).

${ }^{46}$ Janssens, supra note 39, at 257-70. For a general account, see Kalypso Nicolaidis, Mutual Recognition: Promise and Denial, from Sapiens to Brexit, 70 CURREnT LEgAL Probs. 1-40 (2017).
} 
the jurisdictions taking part in this regulatory arrangement will have legal effect in the territory of the others, thus giving rise to cross-border or horizontal interactions.

It is readily apparent that using this broad definition of mutual recognition here does not exclude other ways of understanding it. These alternative approaches could certainly be more accurate in particular areas of law-such as the law of the internal market ${ }^{47}$ or the area of freedom, security, and justice. ${ }^{48}$ Even within the law of the internal market we can find different notions of mutual recognition. For instance, while in some policy areas secondary legislation provides administrative decisions of national authorities with automatic transnational effects throughout the territory of the EU, under the fundamental freedoms, host authorities might rather be compelled to take the law of origin into account, and to assess whether the public interest at stake is effectively protected. ${ }^{49}$ Furthermore, despite the fact that in internal market law mutual recognition is very often conditioned to both home and host legal orders providing the protected interest at stake with equivalent protection, ${ }^{50}$ even in this context, there are areas of law where mutual recognition has been imposed without any form of equivalence test. ${ }^{51}$ There are, in sum, different ways of understanding mutual recognition, even within specific areas of EU law. However, the said common traits can be found in the legal framework of various policy areas, and this has given rise to a general and cross-sectoral approach to mutual recognition. ${ }^{52}$

As it is understood here, the notion of mutual recognition has a very wide scope, yet it does also have clear boundaries. As for the former, it covers two main scenarios of horizontal interaction between national authorities of the Member States, that are here considered as mutual recognition situations. On the one hand, rules or acts subject to mutual recognition are often originally aimed at having legal effects only in the Member State of origin. In these cases, mutual recognition extends those effects to the territory of other Member States. Thus, in Cassis de Dijon, the Court of Justice established that the German authorities had to give effect in the territory of the Member State of destination to the French rules under which the imported product was lawfully produced and marketed in the Member State of origin. ${ }^{53}$ Likewise, in Centros, the Court of Justice granted transnational legal effects to the registration of a firm as a public limited company

\footnotetext{
${ }^{47}$ See, e.g., Miguel Poiares Maduro, We the Court (1998); Catherine Barnard \& Simon Deakin, Market Access and Regulatory Competition, in The LAW OF THE Single European MARKet 197-224 (Catherine Barnard \& Joanne Scott eds., 2002); Kenneth Armstrong, Mutual Recognition, in The Law of The Single European Market 225-67 (Catherine Barnard \& Joanne Scott eds., 2002); Markus Möstl, Preconditions and Limits of Mutual Recognition 47 COMMON MKT. L. Rev. 405-36 (2010); Jacques Pelkmans, Mutual Recognition: Economic and Regulatory Logic in Goods and Services, in Research Handbook on the Economics of EU LAW 113-45 (Thomas Eger \& Hans-Bernd Schaffer eds., 2012); WulfHenning Roth, Mutual Recognition, in RESEARCH HANDBOoK ON THE LAW OF THE EU's INTERNAL MARKET 427-59 (Panos Koutrakos \& Jukka Snell eds., 2017); Stephen Weatherhill, The Principle of Mutual Recognition: It Doesn't Work Because It Doesn't Exist, Eur. L. Rev. 224-33 (2018).

${ }^{48}$ See Annika Souminen, The Principle of Mutual Recognition in Cooperation in Criminal Matters (2011); Valsamis Mitsilegas, Mutual Recognition, Mutual Trust and Fundamental Rights after Lisbon, in RESEARCH HANDBOOK ON EU CRIminal LAW 148-67 (Valsamis Mitsilegas, Maria Bergström \& Theodore Konstadinides eds., 2017); CHRISTOPH Burchard, Die Konstitutionalisierung Der Gegenseitigen Anerkennung: Die strafjustizielle Zusammenarbeit IN EUROPA IM Lichte DES UnionsverfassungSRECHTS (2019).

${ }^{49}$ Roth, supra note 41 , at $428,436$.

${ }^{50}$ Armstrong, supra note 41 , at 233-35.

${ }^{51}$ JANSSENS, supra note 39 , at 40-41, 123.

${ }^{52}$ See Janssens, supra note 39; Nicolaidis, supra note 40; Wouter VAN BAllegooij, The Nature of Mutual Recognition in European Law (2015); Kalypso Nicolaidis, The Cassis Legacy: Kir, Banks, Plumbers, Drugs, Criminals and Refuges, in EU LAw STORIEs 278-301 (Fernanda Nicola \& Bill Davies eds., 2017). See also the contributions published in The Principle of Mutual Recognition in the European Integration Process (Fiorella Kostoris \& Padoa-Schioppa eds., 2005); El reconocimiento mutuo en el Derecho español y europeo (Luis Arroyo Jiménez \& Adan Nieto Martín eds., 2018).

${ }^{53}$ ECJ, Case C-120/78, Rewe-Zentral AG v. Bundesmonopolverwaltung für Branntwein, ECLI:EU:C:1979:42 (Feb. 20, 1979), http://curia.europa.eu/juris/liste.jsf?language $=$ en\&jur=C,T,F\&num =120/78\&td=ALL.
} 
according to the law of England and Wales. ${ }^{54}$ Lastly, a national marketing authorization for a veterinary medicinal product valid in a single Member State must eventually be recognized in other Member States in accordance with a mutual recognition procedure. ${ }^{55}$

On the other hand, decisions taken by one Member State can also be originally designed to have legal effects throughout the EU territory. Secondary law sometimes grants this effect to national enforcement measures, thus giving rise to automatically transnational—mainly administrativeacts. ${ }^{56}$ For instance, for national marketing authorizations for a veterinary medicinal product valid in several Member States, the application is submitted to one of the Member States and, after a composite horizontal procedure with the participation of the other Member States, the reference Member State takes a decision which has transnational legal effects in the territory of all the Member States concerned. ${ }^{57}$

Mutual recognition is thus conceived here as comprising: (i) Rules or acts aimed at having legal effects in the territory of the Member State of origin that nonetheless gain transnational effects, as well as (ii) automatically transnational decisions provided for by EU secondary law that foresees transnational EU-mainly administrative-law enforcement. Despite the many and important differences between these two mutual recognition scenarios, they have an analogous structure and bring about similar problems from the perspective of judicial protection.

However, there are other horizontal interactions between the Member States that are not covered by this wide notion of mutual recognition. Indeed, it excludes other regulatory arrangements where national rules or acts are directly and exclusively intended to have legal effects vis-a-vis the authorities of other Member States, but not in the Member State of origin itself. For instance, preparatory measures taken by the administrative authority of one Member State that form part of a horizontal composite decision-making procedure are not intended to produce effects in the territory of the Member State of origin. ${ }^{58}$ Likewise, judicial or administrative requests of horizontal cooperation addressed to the authorities of other Member States do actually have legal effects in the territory of the latter but are not mutual recognition examples either. ${ }^{59}$ These two regulatory arrangements are conceptually different from mutual recognition, despite both having significant similarities-namely, their transnational legal effects, the gaps in judicial control arising thereof, and the role of the principle of sincere cooperation in terms of coping with them. These similarities will be invoked later, in order to build analogical arguments aimed at solving judicial control blind spots in mutual recognition cases.

\section{Forms}

Within the broad definition outlined above, various distinctions can be made. They can help us to understand how mutual recognition behaves and will later be used to search for gaps in effective judicial protection. First, the legal obligation embodied in this notion of mutual recognition can be from various sources. It can arise from a cooperation agreement between the competent

\footnotetext{
${ }^{54}$ ECJ, Case C-212/97, Centros Ltd. v. Erhvervs-og Selskabsstyrelsen, ECLI:EU:C:1999:126 (Mar. 9, 1999), para. 2, http:// curia.europa.eu/juris/liste.jsf?language $=$ en $\&$ num $=c-212 / 97$.

${ }^{55}$ Commission Regulation 2019/6, arts. 46, 47, 51 \& 52, 2019 O.J. (L 4) 43. See also Directive 2001/83/EC, art. 28(2), 2001 O.J. (L 311) 67; Sabrina Röttger-Wirtz \& Mariolina Eliantonio, From Integration to Exclusion: EU Composite Administration and Gaps in Judicial Accountability in the Authorisation of Pharmaceuticals, 10 EUR. J. RISK REG. 396-401 (2019). See generally Gernot Sydow, VerwaltungSKooperation In DER Europäischen UNiON 181-216 (2004).

${ }^{56}$ Luca De Lucia, From Mutual Recognition to EU Authorisation: A Decline of Transnational Administrative Acts?, 8 IT. J. PuB. L. 94-99 (2016).

${ }^{57}$ Commission Regulation 2019/6, supra note 49, at arts. 48 \& 49. See also Directive 2001/83/EC, supra note 49, at art. 28(3); Röttger-Wirtz \& Eliantonio, supra note 49. See generally SyDow, supra note 49, at 138-80.

${ }^{58}$ Commission Regulation 2020/402, arts. 1 \& 2, 2020 O.J. (L 771) 1 (stating that, in order to grant an export license, the competent national authorities have to consult the authorities of the Member State where the products are physically located). Arroyo Jiménez \& Eliantonio, supra note 4.

${ }^{59}$ See, e.g., Council Directive 2010/24, 2010 O.J. (L 84) 1.
} 
authorities of the jurisdictions that take part in this regulatory arrangement- "agreed mutual recognition." It is more frequent, though, that this obligation is imposed on them by virtue of a higher law- "compulsory mutual recognition." While in the former case mutual recognition arises in a horizontal, voluntary framework, in the latter, it has a constitutional or supranational legal authority, and expresses a vertical, hierarchical relationship. Mutual recognition among national authorities of the Member States of the EU mostly arises from EU law and is of a compulsory nature. Agreed mutual recognition, in turn, is more frequent within the multilevel administrative structure of some of its Member States. ${ }^{60}$

Second, mutual recognition can be proclaimed on a general basis in a constitutional or supranational norm and subject to subsequent interpretation by courts- "judicial mutual recognition"- or it can be enshrined in secondary sources of law, either on a general or on a sectoral basis- "legislative mutual recognition." 61 This is a major difference between mutual recognition in the internal market, where secondary legislation coexists with mutual recognition obligations directly arising from the fundamental freedoms enshrined in the Treaties, and in the area of freedom, security, and justice, where the Treaties do not directly provide for mutual recognition obligations and, therefore, there can be no mutual recognition scheme without the intervention of the European legislator. ${ }^{62}$

Third, the obligation arising from mutual recognition can also be unconditional, and therefore definitive- "absolute mutual recognition"—or, as is more often the case, remain subject to certain conditions, or exceptions- "conditional mutual recognition." ${ }^{63}$ In the law of the internal market, judicial mutual recognition is subject to a rule of reason, ${ }^{64}$ and secondary law usually provides for a system of exceptions that can be defined either on a general basis, or regarding only one specific policy area ${ }^{65}$ Absolute mutual recognition is rather exceptional. ${ }^{66}$ In the area of freedom, security, and justice, mutual recognition is limited by a number of exceptions. While some of them are specifically provided for by the relevant secondary legislation, ${ }^{67}$ others relate to the protection of fundamental rights. ${ }^{68}$

Finally, mutual recognition obligations sometimes require that the rule or act passed by the home authorities directly and autonomously produce legal effects in the territory of other jurisdictions- "passive mutual recognition." EU law does not here establish an obligation to merely take it into account on the part of the authorities of destination. Rather, it grants automatic transnational effects to the administrative decision of origin. In other cases, the obligation incumbent on the host authorities to give effect to them requires their incorporation in a specific and

\footnotetext{
${ }^{60}$ See, e.g., Paulina Starski, Der interföderale Verwaltungsakt 241-64 (2014); Jorge Agudo González, La Extraterritorialidad de las Actuaciones Jurídico-administrativas de las Comunidades Autónomas, 206 REVISTA DE Administración Pública 99-145 (2018); Luis Arroyo Jiménez, Mutual Recognition in the Spanish Multi-level Administrative State, 13 REv. Eur. AdmIN. L. 161-86 (2020).

${ }^{61}$ Pelkmans, supra note 41; JANSSENS, supra note 39, at 10.

${ }^{62}$ Möstl, supra note 41 , at $410-22$.

${ }^{63}$ Roth, supra note 41 , at 458-59; Weatherhill, supra note 41 , at 224-33.

${ }^{64}$ JANSSENS, supra note 39 , at $40-65$.

${ }^{65}$ Id. at $86-105$.

${ }^{66}$ JANSSENS, supra note 39, at 126-28. See, e.g., Council Directive 2006/126, art. 2, 2006 O.J. (L 403) 18 (EC). See ECJ, Case C-467/10, Akyüz, ECLI:EU:C:2012:112 (Mar. 1, 2012), para. 40, http://curia.europa.eu/juris/liste.jsf?num=C-467/10\& language $=E N$; ECJ, Case C-419/10, Wolfgang Hofmann v. Freistaat Bayern, ECLI:EU:C:2012:240 (Apr. 26, 2012), paras. 43, 44, http://curia.europa.eu/juris/liste.jsf?num=C-419/10\&language=EN; ECJ, Case C-260/13, Sevda Aykul v. Land Baden-Württemberg, ECLI:EU:C:2015:257 (Apr. 23, 2015), para. 45, http://curia.europa.eu/juris/liste.jsf?num=C-260/13; ECJ, Case C-195/16, Criminal Proceedings Against I, ECLI:EU:C:2017:815 (Oct. 26, 2017), para. 34, http://curia.europa. eu/juris/liste.jsf?language $=$ en \&num $=\mathrm{C}-195 / 16$.

${ }^{67}$ JANSSENS, supra note 39, at 199-233.

${ }^{68}$ Id. at 159-60, 205-10; Mitsilegas, supra note 42; Marta Muñoz de Morales, El Reconocimiento Mutuo en Materia Penal y Los Derechos Fundamentales, in El Reconocimiento Mutuo en el Derecho Español y Europeo 243-304 (Luis. Arroyo Jiménez \& Adan Nieto Martín eds., 2018).
} 
subsequent decision-making process_- "active mutual recognition." ${ }^{\prime 2}$ The latter is the case in the area of freedom, security, and justice, ${ }^{70}$ as well as in many areas of the internal market. ${ }^{71}$ Instances of passive mutual recognition are, in turn, rather exceptional. ${ }^{72}$

Both in the law of the internal market and in the area of freedom, security, and justice, mutual recognition obligations are conditional on the fulfilment of certain requirements, and/or subject to a subsequent procedure. While the former relates to the substantive dimension of the mutual recognition obligation, the latter has more to do with how this obligation is procedurally articulated. Either way, mutual recognition is very rarely unconditional, "absolute mutual recognition," and automatic, "passive mutual recognition," because even in areas with far-reaching mutual recognition obligations there might be grounds for non-recognition, as well as a margin for ex ante or ex post control by the authorities of the host Member State. ${ }^{73}$ Managed mutual recognition is the expression proposed by Kalypso Nicolaidis to encapsulate this notion. Whereas pure mutual recognition operates unconditionally and automatically, managed mutual recognition provides for a more nuanced regulatory arrangement that circumscribes it from different perspectives - scope of application, pre-existing conditions for equivalence, varying degrees of automaticity, and ex post safeguards. ${ }^{74}$ As will be seen, the fact that the host authorities take actions aimed at enabling, conditioning, or preventing home authorities' decisions from having transnational legal effects will decisively affect the terms in which effective judicial protection will be provided by courts.

\section{European Administrative Space}

As it has been already mentioned, this Article is not concerned with effectiveness of judicial protection in all instances of mutual recognition. Rather, our emphasis is on gaps in judicial review in horizontal interactions in the European administrative space. These arise when administrative law rules and administrative decisions of the Member State of origin have transnational effects. Accordingly, we leave aside mutual recognition of judicial rulings-which bring about different problems, from both a structural and a judicial protection perspective. Even with this restriction in mind, the various forms of mutual recognition that have been previously mentioned may pose different problems from an analytical and public policy approach. The effectiveness of judicial control may also be affected in a different manner depending on how mutual recognition operates in the area of law at stake. Thus, judicial, managed, and active mutual recognition-as opposed to legislative, absolute, and passive mutual recognition — can bring about a significant amount of uncertainty as regards the law that the authorities of the destination State must implement, as well as to the standards of review that are to be applied by judicial authorities. ${ }^{75}$ Moreover, such an uncertainty may also diminish the degree of effectiveness of judicial protection provided for by the courts of destination.

However, regardless of the form in which mutual recognition operates, in the European administrative space judicial control arises in a similar vein from a structural perspective. Indeed, the constellation of relevant cases will refer to scenarios that have three features. The first feature is a decision taken by the administrative authorities of the Member State of destination that conveys a certain stance regarding the application of mutual recognition to a foreign product, service, or person. This decision can be either an ex ante administrative decision-for example granting or rejecting a license - or an ex post administrative decision — such as an order to cease an activity, withdrawal of a previously granted license, or an administrative sanction. In both cases, the courts of the State of

\footnotetext{
${ }^{69}$ Armstrong supra note 41, at 240-42; De Lucia, supra note 50, at 94-99.

${ }^{70}$ JANSSENS, supra note 39, at 254-55.

${ }^{71}$ See, e.g., Council Directive 2005/36, art. 10, 2005 O.J. (L 255) 22 (EC).

${ }^{72}$ See, e.g., Council Directive 2006/126, supra note 60, at art. 2.

${ }^{73}$ JANSSENS, supra note 39 , at 311-12.

${ }^{74}$ Nicolaidis, supra note 46 , at $278-301$.

${ }^{75}$ Armstrong, supra note 41 , at 243.
} 
destination will enter into play in order to control the legality of an administrative decision taken by the host authorities. The second feature is that such a decision affects an individual or firm whose rights or obligations might be-either totally or partially-affected by a rule or act passed by the authorities of the Member State of origin - for example, a rule that protects the right to perform an activity on a general basis, an administrative decision declaring such a right in a particular case, an administrative certificate stating certain facts, and so on. The third feature is the condition that mutual recognition - in any of its abovementioned possible versions - applies and, therefore, the authorities of the Member State of destination are compelled to give effect to the latter.

The type of cases we will deal with contain these three features. In Cassis de Dijon ${ }^{76}$ for instance, Rewe-Zentral AG applied to the German administration of spirits for authorization to import the product in question, which was lawfully produced and marketed in France. The German authorities rejected the application because, under the law of destination, it did not have the characteristics required in order to be marketed within Germany. The importer then challenged the rejection before a German court. In Corsten, ${ }^{77}$ an architect contracted with an undertaking established in the Netherlands to carry out work in Germany. The undertaking entrusted with the work lawfully carried out this activity in the home Member State but was not entered on the Skilled Trades Register in Germany. Accordingly, the German administration fined the architect for breach of the host legislation that required registration. The architect then challenged the fine before a German court. In Wiedemann ${ }^{78}$ the German administration declared that a driving license issued by the Czech Republic did not authorize the holder to drive motor vehicles in Germany, on the ground that he had not, pursuant to German law, demonstrated that he was fit to drive such vehicles. The permit holder challenged the administrative act before a German court.

\section{Searching for Blind Spots}

All these cases raise several distinctive problems in terms of judicial review that can be assessed from the perspective of the right to effective judicial protection. Next, we will examine what kind of effective judicial protection private parties can find in the courts of the States of destination and of origin. In particular, effectiveness can be weighed here in both procedural and substantive terms. Despite the fact that the distinction between procedure and substance can sometimes be blurred, it will help us to structure our reasoning.

\section{Procedure}

From a procedural standpoint, blind spots in judicial protection can arise from two distinct, yet intertwined, circumstances. The first is the limited competence of the courts of the Member State of destination. The second is brought about by limitations to access to the courts of the Member State of origin. A possible answer to these problems is exploring, and exhausting, the competence of the courts of destination.

\section{Competence}

As a general rule, in multi-jurisdictional contexts the principle of separation applies: administrative rules or acts must be challenged before the courts of the jurisdiction of the authorities that have enacted them. The principle of separation is characteristic of the relationship between autonomous legal orders: A legal system-and its institutional actors - can decide on the efficacy,

\footnotetext{
${ }^{76}$ Rewe-Zentral $A G$, Case C-120/78.

${ }^{77} \mathrm{ECJ}$, Case C-58/98, Joseph Corsten, ECLI:EU:C:2000:527 (Oct. 3, 2000), http://curia.europa.eu/juris/liste.jsf?num= C-58/98.

${ }^{78}$ ECJ, Case C-329/06, Wiedemann v. Baden-Württemberg, ECLI:EU:C:2008:366 (June 26, 2008), http://curia.europa.eu/ juris/liste.jsf?num $=\mathrm{C}-329 / 06 \&$ language $=\mathrm{en}$.
} 
that is, applicability, or recognition as having effects in its territory of rules passed within another legal system. ${ }^{79}$ In turn, validity-namely existence in a given legal order, or recognition as a rule that belongs to it-is a property of rules that can only be assessed in view of the legal system within which they have been passed. ${ }^{80}$ This is common ground in the context of the relationship between the law of the EU and the law of its Member States, where competence of EU and national courts is shared according to the principle of separation — which has also been called "double exclusivity." 81 Competence of national courts is distributed between the Member States following this same criterion. Courts of the Member State of destination are not empowered to annul-to declare null and void-administrative rules or acts adopted by other Member States. ${ }^{82}$ Validity of rules and acts of the Member State of origin can only be assessed by the courts of the State of origin. Consequently, national administrative law rules or administrative decisions of the Member State of origin must be challenged before its own courts.

This scheme for horizontally allocating jurisdiction can make it difficult for individuals or firms established in other Member States to have access to a court and therefore, to obtain effective judicial protection. As long as they have such an effect, rules establishing the boundaries of jurisdiction of the different national courts according to the principle of separation must be seen as restrictions of the principle and fundamental right to an effective judicial protection enshrined in Articles 19(1) TEU and 47 of the Charter and, in particular, restrictions of the right of access to a court, which must be construed in view of the multijurisdictional nature of EU law. ${ }^{83}$ Natural and legal persons established in the Member State of destination will not be entitled to challenge the said rule or act before the courts of the State of destination in order for the court to annul them. Not being able to seek annulment of a rule or act that directly affects your rights or interests before the courts of the Member State where it is supposed to have legal effect must certainly be qualified as a restriction of the right to effective judicial protection. However, this does not necessarily mean that such a restriction violates this fundamental right under Article 52(1) of the Charter. The limitation of the jurisdiction of the courts of the State of destination is not only a matter of sovereignty ${ }^{84}$; rather, it can also be conceived of as a necessary measure that genuinely meets a purpose of general interest, such as coordinating the exercise of judicial review by national courts in a multi-jurisdictional context. Moreover, the restriction seems to respect the essence of the right of access to a court, because there will normally be an open avenue to challenge the rule or act before the courts of origin, which would in turn be competent to declare them null and void.

\section{Reviewability}

This is not always the case, though. Indeed, the second issue is brought about by limitations to access to the courts of the State of origin laid down by national procedural law. If the transnational

\footnotetext{
${ }^{79}$ Giacinto della Cananea, From the Recognition of Foreign Acts to Trans-National Administrative Procedures, in Recognition of Foreign Administrative Acts 223-25 (Jaime Rodríguez-Arana Munoz ed., 2016).

${ }^{80}$ Hans Kelsen, Pure Theory of Law 197 (1967); Juan Luis Requejo Pagés, Sistemas Normativos, Constitución y ORDENAMIENTO 10, 76 (1995).

${ }^{81}$ Brito Bastos, supra note 11; Barbara Marchetti, Il Sistema Integrato di Tutela, in L'AMministrazione EUROPEA E LE SUE REgule 198 (Luca de Lucia \& Barbara Marchetti eds., 2015). See, e.g., ECJ, Case C-314/85, Foto-Frost v. Hauptzollamt LübeckOst., ECLI:EU:C:1987:452 (Apr. 22, 1987), http://curia.europa.eu/juris/liste.jsf?language=en\&jur=C,T,F\&num=314/85\&td= ALL; ECJ, Case C-97/91, Oleificio Borelli SpA v. Comm'n of the European Communities, ECLI:EU:C:1992:491 (Dec. 3, 1992), http://curia.europa.eu/juris/liste.jsf?language $=$ en $\&$ num $=c-97 / 91 \& t d=A L L$. For the fissures in this principle, see ECJ, Case C.219/17, Berlusconi v. Banca d'Italia, ECLI:EU:C:2018:1023 (Dec. 19, 2018), http://curia.europa.eu/juris/liste.jsf?language=en\& td=ALL\&num=C-219/17; ECJ, Joined Cases C-202 \& 237/18, Rimsevics v. Latvia, ECLI:EU:C:2019:139, Judgment of 26 Feb. 2019.

${ }^{82}$ See the national reports published in Recognition of Foreign Administrative Acts (Jaime Rodríguez-Arana ed., 2016).

${ }^{83}$ See supra Section B(I)(4).

${ }^{84}$ Della Cananea, supra note 73 , at 224 .
} 
measure is a final single case administrative decision-one granting or revoking a license, imposing a fine, ordering an activity to be ceased, and so on-this will not be a problem. On the contrary, if it is a rule-such as a general authorization, ${ }^{85}$ or a non-final, preparatory measure, for example, the results of a technical test performed within administrative proceedings ${ }^{86}$ - national procedural law of the Member State of origin can impede or restrict judicial review. ${ }^{87}$ The same can happen with final administrative acts that contain no regulatory decision-such as a declaration of legal rights or obligations, but administrative information about individuals or firmsincluding tax or exams certificates. The reason is that, in some national legal orders, they cannot be amenable to direct judicial review. ${ }^{8}$ In turn, they must be indirectly controlled by means of an action challenging a subsequent decision, be it a definitive decision that puts an end to the administrative procedure, in the case of preparatory measures, or a single case implementing measure, in the case of rules, and acts without regulatory content. This avenue can be closed off, though, in transnational settings, where the subsequent decision is taken by the authorities of other Member States-for example, the order to cease an activity taken by the authorities of destination in view of the information provided by the authorities of origin in a technical test or in a certification issued by the authorities of origin.

The consequence of this is that there might be transnational rules and acts that cannot be challenged before the courts of destination by virtue of the mentioned principle of separation, nor before the courts of origin, because of the limitations on reviewability established by national procedural law. Crucially, such a gap in judicial review has an impact on a dimension of the fundamental right to effective judicial protection where it does not function as a principle-namely, not as a mandate of optimization-but as a rule-namely, an indefeasible norm. While access to a court can be proportionally restricted by procedural law establishing standing requirements, time limits, and so on, there might be no abstract categories of rules or acts outside the scope of judicial control, whether direct or indirect. ${ }^{89}$

\section{Strengthening the Courts of Destination}

A way to address these problems is to understand that, when reviewing the decision taken by the authorities of the Member State of destination regarding an individual or firm whose rights or obligations might be affected by transnational rules or acts, the courts of destination will be competent to assess whether and to what extent they are required to give them effect by virtue of a mutual recognition obligation. A sensitive issue that will be tackled later is that of the substantive scope of such an assessment. From a procedural point of view, though, this avenue is open insofar as actions are not brought against the rule or act of origin, but against the decision of the authorities of the Member State of destination whereby they recognize, reject, or qualify the transnational effects of the former. A court ruling on this kind of decision, taken by administrative or judicial authorities of the Member State of destination, will not have jurisdiction to annul rules or acts of origin, but will have jurisdiction to decide on whether they must be granted or deprived from legal effects in their territory. In other words, they have no jurisdiction to decide on their validity, but they certainly have jurisdiction to decide on their transnational applicability.

Judicial control by the courts of the State of destination of the transnational effects of rules or acts of origin contributes to solving the two mentioned procedural difficulties. As regards the first difficulty, it has already been submitted that limitations on the right of access to a court arising from the principle of separation are necessary measures to coordinate the action of courts that

\footnotetext{
${ }^{85}$ Mariolina Eliantonio \& Franziska Grashof, Types of Administrative Action and Corresponding Review, in JUDICIAL Review of Administrative ACTion 133-52 (Chris Bakes \& Mariolina Eliantonio eds., 2020).

${ }^{86}$ Eliantonio \& Grashof, supra note 79 , at $152-58$.

${ }^{87}$ Opinion of Advocate General Bobek at para. 90, Case C-557/16, Astellas Pharma GmbH (Mar. 14, 2018).

${ }^{88}$ Eliantonio \& Grashof, supra note 79 , at $125-33$.

${ }^{89}$ See supra Section $\mathrm{B}(\mathrm{I})(3)$.
} 
participate in the EU multi-jurisdictional judicial system. Furthermore, it is readily apparent that the competence of the courts of destination to recognize, reject, or qualify the transnational legal effects of foreign rules and acts significantly reduces the intensity of the restriction of the fundamental right, and this facilitates the justification of its proportionality. Admittedly, they will not be entitled to annul them. However, deciding on their legal effects in the territory of the Member State of destination is a functional equivalent to that.

Regarding the second constitutional problem, its contribution is even more crucial. In case the rule or act of origin is not reviewable before the courts of the Member State of origin under its domestic procedural legislation, Article 47 of the Charter must be construed as unconditionally requiring access to a court. In other words, in this particular scenario, the right of access to a court would not function as a principle, but as a rule. Accepting the jurisdiction of the courts of the Member State of destination to decide on the transnational legal effects of rules or acts that are not reviewable in the Member State of origin helps to fill this gap.

The application of this solution to mutual recognition cases can be grounded on an analogy with Berlioz ${ }^{90}$ a case where the Court of Justice dealt with a horizontal cooperation arrangement between tax administrations of two Member States. ${ }^{91}$ Following a request for information made by the French authority, ${ }^{92}$ the Luxembourg tax administration required Berlioz to provide certain information. As the firm did not comply with the request, the Luxembourg authorities imposed a fine on it. According to national law, Berlioz could challenge the administrative fine, which was a definitive measure taken by the Luxembourg authorities, but not the previous decision taken by the same authorities requiring the requested information to be provided, nor the request for exchange of information issued in the first place by the French tax administration. The Court of Justice ruled that the right to effective judicial protection enshrined in Article 47 of the Charter, and specifically, the right of access to an independent and impartial tribunal, requires that "a decision of an administrative authority . . . must be subject to subsequent control by a judicial body that must, in particular, have jurisdiction to consider all the relevant issues." 93 Consequently, Luxembourg courts "hearing an action against the pecuniary administrative penalty imposed on [Berlioz] for failure to comply with an information order must be able to examine the legality" of the latter. ${ }^{94}$ Moreover, the right to effective judicial protection also requires that, when reviewing the legality of the information order, the court carries "out the review of the legality of the request for information," 95 with the limitations that also apply to the requested administrative authority. ${ }^{96}$

Berlioz does not exactly deal with a mutual recognition case, but with a request for administrative information exchange. If the Luxembourg authorities were compelled to collect this information and to convey it to the French authorities, it was not by virtue of a mutual recognition obligation, but under the duties laid down in secondary legislation under the principle of sincere cooperation. However, there are some similarities between these two forms of transnational interactions that, as has been said above, relate to significant circumstances in terms of whether and

\footnotetext{
${ }^{90}$ Hofmann supra note 2; Berlioz, Case C-682/15. See Leo Neve, The Berlioz-Decision of the CJEU Provides Protection for Concerned Persons in Transnational Setting, But Will it Hold in the International Area?, 10 ReV. EuR. AdMIN. L. 95-119 (2017); D. Berlin, Souveraineté et protection des droits fondamentaux. CJUE, gde ch., 16 mai 2017, Berlioz Investment Fund SA / Directeur de l'administration des contributions directes, aff. C-682/15, 2017/2 307-320 REVUE DES AFFAIRES Europeennes (2017); Paolo Mazzotti \& Mariolina Eliantonio, Transnational Judicial Review in Horizontal Composite Procedures: Berlioz, Donnellan, and the Constitutional Law of the Union, 5 EUR. PAPERS 41-70 (2020).

${ }^{91}$ Directive 2011/16 of the Council of 15 February 2011 on Administrative Cooperation in the Field of Taxation and Repealing Directive 77/799/EEC, 2011 O.J. (L 64) 1.

${ }^{92}$ Id. at arts. $1(1)$.

${ }^{93}$ Berlioz, Case C-682/15 at para. 55.

${ }^{94} I d$. at para. 56.

${ }^{95} \mathrm{Id}$. at para. 84 .

${ }^{96} I d$. at para. 85 .
} 
how gaps in judicial protection must be filled. First, in both cases national authorities are forced to give effect to an administrative measure taken by the authorities of another Member State. Second, under domestic law, national courts have no jurisdiction whatsoever to review the validity of foreign administrative measures. Third, challenging these measures before the courts of the Member State whose administrative authorities issued them might well be precluded under national law because of their preparatory nature or for other reasons. Consequently, the regulatory framework leads, in both cases, to a severe reduction of the effectiveness of judicial protection because the legality of the relevant preparatory measure would not be reviewed by any national jurisdiction. As the Court of Justice made clear in Berlioz, these situations are prohibited by Article 47 of the Charter.

It would therefore seem reasonable to apply the Berlioz solution by analogy to the judicial review of other horizontal administrative interactions, such as those arising from horizontal composite procedures, ${ }^{97}$ and from mutual recognition obligations. Accordingly, when reviewing the decision by which the administrative authorities of destination recognize, reject, or qualify the transnational effects of the foreign rule or act, the courts of destination must be able to "carry out the review of the legality" of the decision, despite it being issued by the administrative authorities of another Member State. Another issue altogether is that of the substantive scope of such a review.

\section{Law}

Effective judicial protection in mutual recognition cases can also be assessed from a substantive perspective. The focus will no longer be on which procedural avenues to access a court remain open, namely not on the scope or extension of the right to effective judicial protection, but on the extent to which the court can examine the relevant questions at stake-for example, the intensity of the right to effective judicial protection. More precisely, the group of cases outlined above ${ }^{98}$ bring our attention to the courts of the Member State of destination, the intervention of which would be triggered by actions lodged against decisions whereby its administrative authorities recognize, reject, or qualify the transnational legal effects of rules or acts taken by the authorities of origin. As has been explained, the right to effective judicial protection prima facie requires that the courts of the State of destination could examine all the facts and legal issues that might be relevant to the dispute. ${ }^{99}$ The scope of their review, however, can be restricted in order to comply with competing principles and interests in accordance with the principle of proportionality. In transnational settings, this can bring about various distinctive problems. I will now focus on one of them: What law must be applied by the courts of destination when it comes to reviewing administrative acts that give-or refuse to give-effect to a rule or act previously adopted in another Member State. Despite the specific combination depending on the area of law at stake, as well as on the domestic legislation of the Member State where the case arises, three legal orders will potentially come into play.

\section{EU Law}

First, in the group of cases we are dealing with, the mutual recognition obligation of the Member State of destination originates in EU law, which also establishes substantive and procedural conditions for it to apply and regulates the possible exceptions. Consequently, EU law will necessarily be applied by the courts of destination when deciding on the legality of the administrative decision taken by the authorities of destination. In judicial mutual recognition cases, the courts of

\footnotetext{
${ }^{97}$ Hofmann, supra note 2, at 20-21; Mazzotti \& Eliantonio supra note 84, at 47-55; Arroyo Jiménez \& Eliantonio, supra note 4 , at $384-88$.

${ }^{98}$ See supra Section B(III).

${ }^{99}$ See supra Section $\mathrm{B}(\mathrm{I})(3)$.
} 
destination are bound by the fundamental freedoms enshrined in the Treaty and must interpret the relevant provisions in the light of the rule of reason construed by the Court of Justice's case law. In Bosman, for instance, the Belgian Court of Appeals had to interpret Article 48 of the Treaty of the European Economic Community, ${ }^{100}$ while in Gebhard, the reference for a preliminary ruling was made seeking the interpretation of Articles 52 and 59 of that Treaty. ${ }^{101}$ In legislative mutual recognition cases, the courts of destination are also bound by secondary acts that outline the mutual recognition obligation from both a procedural and substantive perspective. Thus, in Gebhard, the national authorities also had to interpret Directive 77/249/EEC on services provided by lawyers. ${ }^{102}$ Likewise, in Laval, the Swedish court made a reference for a preliminary ruling on the interpretation of Directive 96/71/EC on posted workers. ${ }^{103}$

But the courts of the Member State of destination will not only be entitled to apply EU law to the administrative decision of its domestic authorities. They can also apply EU law to the transnational measure in order to decide whether or not to grant it effects in its territory. This was declared by the Court of Justice in Berlioz regarding the judicial assessment of a foreign request for tax information, a doctrine that might well be analogically applied to mutual recognition cases. The Court ruled that the Luxembourg courts had competence to assess whether the cooperation request issued by the French tax administration complied with Article 1(1) of the Directive on administrative cooperation in the field of taxation. ${ }^{104} \mathrm{~A}$ different issue altogether, as will be immediately made clear, is whether and to what extent the courts of destination must defer to the decision taken by the foreign authorities. ${ }^{105}$

\section{The Law of Destination}

Second, the law of the Member State of destination will normally remain applicable regarding the procedural, formal, and organizational requirements of the challenged administrative decision. Thus, in a case like Gebhard, triggered by a disciplinary sanction imposed by a professional body on a foreign service provider, ${ }^{106}$ national courts can verify whether the sanction complies with procedural and substantive requirements laid down by domestic legislation-requirements such as competence, due process, and so on. Moreover, the law of destination will also be applicable to review the substance of the administrative decision as long as EU law does not impose an absolute mutual recognition scheme. Exceptions to mutual recognition obligations arising from either the Treaty or secondary legislation in fact give rise to the application of the law of destination as long as it does not infringe EU law. Thus, the German authorities decided, in Wiedemann, that the holder of a Czech driving license had not, pursuant to German law, demonstrated that he was fit to drive motor vehicles. ${ }^{107}$ In the review of the administrative decision, the German administrative court therefore had to interpret and apply German law. Likewise, in the Jany case, the Dutch authorities rejected applications for residence permits enabling prostitutes to work on a self-employed basis on the ground that prostitution was a prohibited activity in the Member State of destination. The reviewing court therefore had to decide on the legal status of prostitution under Dutch law and declared that certain forms of it were permitted in the Netherlands and even

\footnotetext{
${ }^{100}$ ECJ, Case C-415/93, Union royale belge des sociétés de football association v. Bosman, ECLI:EU:C:1995:463 (Dec. 15, 1995), http://curia.europa.eu/juris/liste.jsf?num=C-415/93.

${ }^{101}$ ECJ, Case C-55/94, Gebhard v. Consiglio dell'Ordine degli Avvocati e Procuratori di Milano, ECLI:EU:C:1995:411 (Nov. 30, 1995), http://curia.europa.eu/juris/liste.jsf?language $=$ en\&num=C-55/94.

${ }^{102}$ Gebhard, Case C-55/94; Council Directive 77/249, 1977 O.J. (L 78$) 17$.

${ }^{103}$ ECJ, Case C-341/05, Laval un Partneri Ltd. v. Svenskal, ECLI:EU:C:2007:809 (Dec. 18, 2007), http://curia.europa.eu/ juris/liste.jsf?language=en\&num=C-341/05. Council Directive 96/71, 1997 O.J. (L 18) 1 (EC).

${ }^{104}$ Berlioz, Case C-682/15 at para. 89. Council Directive 2011/16/EU of 15 February 2011 on Administrative Cooperation in the Field of Taxation, 2011 O.J. (L 64) 1.

${ }^{105}$ See infra Section C(III).

${ }^{106}$ Gebhard, Case C-55/94.

${ }^{107}$ Wiedemann, Case C-329/06 at para. 28.
} 
regulated at communal level. ${ }^{108}$ All this was possible because, under EU law, the right to establishment-and its corollaries, the rights of entry and residence-can be derogated from on grounds of, inter alia, public policy. ${ }^{109}$ It is, in sum, the exception provided for by EU law that brought domestic legislation to the judicial process.

\section{The Law of Origin}

Third, and certainly more controversially, the courts of the Member State of destination may also have to interpret the law of origin in order to decide whether or not the reviewed decision is correct. Mutual recognition obligations prevent the authorities of destination from applying their domestic legislation to products, services, or persons from other Member States, provided that they comply with the law of origin. ${ }^{110}$ Whether compliance with the law of origin is conceived of under the law of destination as a point of law or as a fact, ${ }^{111}$ as well as whether the courts of destination are called upon to actually implement the law of origin in their territory or if they must simply abide by its content and draw the relevant legal consequences thereofTatbestandswirkung - are here secondary issues. Either way, satisfying the requirements set out by the former is, under EU law, a condition for transnational effects to arise. For example, German authorities were compelled to permit the commercialization of Cassis as long as it was lawfully produced and marketed in France. ${ }^{12}$ Germany was not entitled to require registration to Mr. Corsten's contractors as long as they lawfully carried out work in the Netherlands, ${ }^{113}$ and Mr. Wiedemann, in the end, did actually have a valid Czech driving license. ${ }^{114}$ The courts of destination will, therefore, necessarily assess whether the product, service, or person comply with the law of the Member State of origin, because the transnational effects of the rule or act will be dependent on that compliance. Because the right to effective judicial protection comprises the right to a judicial examination of all legal questions that might be relevant to the dispute, ${ }^{115}$ restrictions of the competence of the courts of destination to interpret and apply the law of origin in mutual recognition cases must be regarded as limitations of the right to effective judicial protection, subject to the conditions set out in Article 52(1) of the Charter.

All this raises another relevant question: Namely, how the courts of destination would cope with uncertainty regarding the content and correct interpretation of the law of origin. Parties in the judicial process before the court of destination will be allowed to claim what the correct interpretation of the law of origin is, as well as to provide evidence thereof. However, in some cases it might be uncertain how the law of origin must be construed and interpreted. Whenever the administrative or judicial authorities of origin have issued an individual decision on the case at stake-be it an administrative license or a judicial decision-uncertainty regarding the content of the law of origin will decrease. Thus, it was not disputed that Mr. Wiedemann complied with Czech law because he held a driving license issued by the authorities of origin. ${ }^{116}$ As we will see later, ${ }^{117}$ the problem will then be the extent to which the authorities of destination are bound by those decisions.

Yet without those decisions the interpretation of the law of origin will necessarily be more difficult. Thus, if a transnational firm submits that, under its domestic legislation, market access

\footnotetext{
${ }^{108}$ ECJ, Case C-268/99, Jany v. van Justitie, ECLI:EU:C:2001:616 (Nov. 20, 2001), paras. 18, 21, http://curia.europa.eu/juris/ liste.jsf?num $=\mathrm{C}-268 / 99$.

${ }^{109} J a n y$, Case C-268/99 at para. 58.

${ }^{110}$ Roth, supra note 40 , at 435.

${ }^{111}$ Della Cananea, supra note 72 , at 224.

${ }^{112}$ Rewe-Zentralfinanz, Case C-33/76 at para. 14.

${ }^{113}$ Joseph Corsten, Case C-58/98 at paras. 41, 47.

${ }^{114}$ Wiedemann, Case C-329/06 at para. 26.

${ }^{115}$ See supra Section $\mathrm{B}(\mathrm{I})(2)$.

${ }^{116}$ Wiedemann, Case C-329/06 at para. 26.

${ }^{117}$ See infra Section C(III)(1).
} 
is not conditional on holding an administrative license, and the administrative authorities of destination argue otherwise, the court of destination will be compelled to interpret the legislation of origin in order to clarify this point of law. The Dutch contractors of Mr. Corsten, for instance, were entitled to access the German market in the exercise of his freedom to provide services, despite not being registered in Germany or in the Netherlands, as long as, under Dutch law, market access was not conditional on prior approval. ${ }^{118}$ Likewise, in Cidrerie Ruwet, the Court of Justice declared that the prohibition of marketing in Belgium of bottles containing 0.33 liters of cider is, in principle, a measure prohibited by the free movement of goods insofar as it applies to imported bottles that are lawfully manufactured and marketed in other Member States. ${ }^{119}$ If this would have been disputed, the court of destination would therefore have had to verify whether or not the imported bottles were legally marketed under the law of origin.

This could also be the case whenever the courts of destination must decide on whether or not the public interest at stake enjoys an equivalent protection under the laws of origin and destination. ${ }^{120}$ In order to make this assessment it might well be necessary to interpret both the law of destination and of origin. Commission v. France is a good example of this. There, the Court of Justice reached the conclusion that the Commission had not demonstrated that German machines provided to their users the same level of protection as French machines, and it based this finding on a systematic and teleological interpretation of the legislation in each country. ${ }^{121}$ Despite this case being an infringement procedure filed by the Commission, the Court's reasoning illustrates the need to interpret both the law of origin and of destination when it comes to assess their equivalence, which, in ordinary horizontal interactions arising from mutual recognition obligations, is the province of the courts of the Member State of destination.

In order to make it possible for the courts of destination to adequately decide on whether the product, service, or person in question actually complies with the law of origin, especially whenever there is no intervention from the administrative or judicial authorities of origin, the scope and limits of the principle of sincere cooperation, under Article 4(3) TEU, must be explored. In particular, the principle can be construed as giving the possibility to request legal opinions about the law of the Member State of origin to its legislative and administrative authorities. A fruitful analogical argument could be made with the Eurobolt case, where the Court ruled that a national court is entitled to "approach an EU institution ... in order to obtain specific information and evidence" from it which might be "essential in order to dispel all doubts which it may have as regards the validity of the EU act concerned." 122 The judgment did not only state that domestic courts could request this information, it also made clear that, according to the duty of sincere cooperation, EU institutions must provide them with the requested information. ${ }^{123}$

The facts in Eurobolt differ from judicial application of foreign law in mutual recognition cases in that the former relate to a vertical relationship — between a national court and EU authoritieswhile the latter give rise to horizontal interactions-between a national court and national authorities of another Member State. However, in both situations, there is (i) a court requesting information and evidence that is relevant to decide a case under EU law, (ii) from non-judicial authorities of other jurisdictions, (iii) that are subject to the duty of sincere cooperation under Article 4(3) TEU. This structural similarity allows us to conclude by analogy that the courts of

\footnotetext{
${ }^{118}$ Joseph Corsten, Case C-58/98 at para. 16.

${ }^{119}$ ECJ, Case C-3/99, Cidrerie Ruwet v. Cidre Stasse, ECLI:EU:C:2000:560 (Oct. 12, 2000), para. 48, 52, http://curia.europa. eu/juris/liste.jsf?language $=$ en $\&$ num $=\mathrm{C}-3 / 99$.

${ }^{120}$ JANSSENS, supra note 39 , at 48-54.

${ }^{121}$ ECJ, Case C-188/84, Commission v. France, ECLI:EU:C:1986:43 (Jan. 28, 1986), http://curia.europa.eu/juris/showPdf.jsf? text $=\&$ docid $=93219 \&$ doclang $=E N$. See also Opinion of Advocate General van Themaat, Case 188/84 Commission v. France (Jan. 28, 1986); JANSSENS, supra note 39, at 50-51.

${ }^{122}$ ECJ, Case C-644/17, Eurobolt, ECLI:EU:C:2019:555 (July 3, 2019), para. 30, http://curia.europa.eu/juris/liste.jsf?num= C-644/17.

${ }^{123}$ Eurobolt, Case C-644/17 at para. 31.
} 
the Member State of destination are entitled to request additional information from the legislative and administrative authorities of origin about what the content of the law of origin is, and how it must be interpreted, and that the latter are compelled to deal with those requests as a matter of EU law. This would fall short of horizontal preliminary rulings between national courts, on both questions of interpretation and validity of the law of origin, that clearly would require a specific legal basis in written law. ${ }^{124}$

In Eurobolt, the request was necessary in order for the national court to decide on making a possible reference for a preliminary ruling to the Court of Justice. Therefore, the judgment grounded the duty to respond to the information request on Article 267 TFEU, read in conjunction with Article 4(3) TEU. ${ }^{125}$ However, it might also be argued, from a more general perspective, that having access to the requested information and evidence makes it possible for the domestic court to take into account a point of law that in mutual recognition cases is undoubtedly relevant. Therefore, answering the request would clearly increase the effectiveness of judicial protection. Consequently, this doctrine could be applied also to cases where the connection with EU law does not arise from a possible reference for a preliminary ruling, but from the enforcement of a mutual recognition obligation. The competence to request information and the duty to respond to that request would, therefore, arise from Article 47 of the Charter, read in conjunction with Article 4(3) TFEU, as the national court had put it in the referred questions in Eurobolt. ${ }^{126}$

\section{Deference}

Another substantive perspective from which to assess how effective judicial protection can be ensured in transnational settings brought about by mutual recognition obligations is deference. As long as it requires that the court in question has the "power to consider all the questions of fact and law that are relevant to the case before it," 127 the fundamental right to effective judicial protection prima facie demands full review of questions of law, fact, and discretion. Consequently, procedural law and practice that provide for the application of more or less deferential standards of review must be conceived of as a restriction of the fundamental right enshrined in Article 47 of the Charter, therefore requiring a constitutional justification in view of Article 52(1) of the Charter. I will now examine this question from the three abovementioned perspectives.

\section{Law}

First, what standard of review of legal statements made by authorities of origin must be applied by the courts of destination? In cases of absolute and passive mutual recognition there is no room for doubt. The authorities of the Member State of destination are unconditionally required to give effect to the transnational rule or act. ${ }^{128}$ Accordingly, its administrative authorities must simply recognize its transnational legal effects, and judicial control by the courts of destination shall guarantee the fulfilment of this obligation. The EU norm that clearly and unconditionally imposes a mutual recognition obligation must be applied, leaving aside any domestic provision, administrative decision, or judicial ruling that precludes the rule or act of origin from having transnational effect. The problem, in turn, arises when mutual recognition is not absolute. As we have seen, the courts of the Member State of destination might be compelled to interpret not only their own

\footnotetext{
${ }^{124}$ Hofmann, supra note 5, at 159 (advocating for horizontal preliminary references of validity to review the input of other national administrations in horizontal composite procedures).

${ }^{125}$ Eurobolt, Case C-644/17 at para. 32.

${ }^{126} I d$. at para. 23.

${ }^{127}$ Europese Gemeenschap, Case C-199/11 at para. 49; Imtech Marine Belgium NV, Case C-300/14 at para. 38. See also Opinion of Advocate General Bobek at para. 103, Case C-89/17, Secretary of State for the Home Department v. Rozanne Banger (Apr. 10, 2018).

${ }^{128}$ See supra Section $\mathrm{B}(\mathrm{II})(2)$.
} 
domestic legal order, but also EU law and the law of origin itself. Must they defer to the authorities of origin with regard to questions of law? In purely internal situations, judicial review of law comprises the possibility of substitution of judgment in case the court finds an error of law. Unlike what occurs under U.S. law, where courts defer to agencies with respect to the interpretation of both statutes that grant them authority-Chevron deference-and rules and regulations that they may enact when performing their rulemaking powers-Auer deference- ${ }^{129}$ in most European national administrative laws, ${ }^{130}$ as well as in EU law, ${ }^{131}$ courts typically subject the interpretation of law made by administrative authorities to full review.

Yet in transnational situations this must be qualified when a court is interpreting foreign law, either directly or through the assessment of the legality of a decision in which a national administrative authority had previously interpreted it. In particular, the administrative and judicial authorities of destination must defer to the authorities of origin when it comes to interpreting the law of origin. The need for deference is readily apparent when the authorities of origin have already taken a stance on the particular case at hand. This can happen, first, when they have taken a decision on the product, service, or person, such as an administrative act granting or revoking a license or registration, an order to cease an illegal activity, or an administrative certification. These administrative decisions can comprise statements on the law of origin, to which the administrative and judicial authorities of the Member State of destination must defer. The same would happen in case the authorities of origin forward a provisional measure or a request for assistance to the administrative authorities of the Member State of destination. Unlike the first group, these administrative acts are specifically directed at the authorities of the Member State of destination. Thus, administrative requests for horizontal administrative cooperation issued by the authorities of origin can also contain their views on how national law must be interpreted. ${ }^{132}$ Finally, legal statements on the law of origin would also be found in the briefs or decisions issued in order to attend requests made by the courts of destination to the authorities of origin regarding specific information about the content of the law of origin under the principle of sincere cooperation. ${ }^{133}$

In all these situations, it is not the province of the courts of destination to second-guess the views of the authorities of origin on how the law of origin must be interpreted or construed. As this is certainly a limitation of the powers of the reviewing courts, it must be conceived of as a restriction of the right to effective judicial protection. However, it can be regarded as an adequate and necessary measure to achieve an objective of general interest recognized by the $\mathrm{EU}$, such as the effectiveness of mutual recognition arrangements and of administrative cooperation mechanisms. In particular, the justification of deference rests on both systematic and epistemological reasons. As for the former, from the perspective of the authorities of destination, the law of origin is not only composed of legal norms - namely, general measures passed in the form of a source of law-but also of those administrative and judicial single-case decisions taken under the authority of the same legal system. Whenever the courts of destination must give effect to the law of origin, this implies giving effect to it as a whole. As for the epistemological

\footnotetext{
${ }^{129}$ See Chevron U.S.A., Inc. v. NRDC, 468 U.S. 837 (1984); Skidmore v. Swift \& Co., 323 U.S. 134 (1944); Auer v. Robbins, 519 U.S. 452 (1996). This is one of the most controversial issues in contemporary U.S. administrative law. For a recent account, see Adrian Vermeule, Law's Abnegation: From Law's Empire to the Administrative State 29-31 (2016); Christopher J. Walker, Attacking Auer and Chevron Deference: A Literature Review, 16 Geo. J.L. Pub. Pol'y 103 (2018); Jeffrey A. Pojanovsky, Neoclassical Administrative Law 133 HARV. L. Rev. 852 (2019); CASS R. SUnSTEIN \& AdRIAN Vermeule, Law \& Leviathan: Redeeming the Administrative State 38-62 (2020); Ronald M. Levin, The APA and the Assault on Deference (January 7, 2021) (unpublished manuscript)(on file with Washington University in St. Louis Law School).

${ }^{130}$ Paul Craig, Judicial Review of Questions of Law: A Comparative Perspective, in Comparative Administrative LAW 389-403 (Susan Rose-Ackerman \& Peter Lindseth eds., 2017).

${ }^{131}$ CRAIG, supra note 23 , at $441-44$.

${ }^{132}$ Berlioz, Case C-682/15 at para. 89.

${ }^{133}$ See supra Section C(II)(3).
} 
reasons, the authorities of origin are in a better position than the courts of destination when it comes to correctly interpreting the law of origin. This point has been made recently by the Court of Justice in Berlioz with regard to horizontal administrative cooperation cases: "[T]he requested authority must, in principle, trust the requesting authority and assume that the request for information ... complies with the domestic law of the requesting authority." This is because the "requested authority does not generally have extensive knowledge of the factual and legal framework prevailing in the requesting State, and it cannot be expected to have such knowledge."134

\section{Fact}

Second, the same question ought to be raised with regard to fact. What standard of review must the courts of the Member State of destination apply regarding factual statements made by the authorities of origin? Both EU and national administrative laws depart here from a more nuanced point: In purely internal situations, courts subject fact to full review, as long as the epistemological objection does not apply. ${ }^{135}$ Accordingly, courts usually defer to administrative authorities when it comes to reviewing complex technical assessments. ${ }^{136}$ If those factual statements have been made by administrative authorities of the Member State of origin, there are, therefore, good reasons for the courts of destination to defer because the epistemological asymmetry would be even greater than in purely internal situations. Moreover, in certain areas of EU law, mutual recognition obligations are imposed on the authorities of destination precisely in order to preclude a new factual assessment in the Member State of destination. ${ }^{137}$ Mutual recognition would force authorities of destination to simply accept and give effect to information and evidence produced by the authorities of origin.

Legitimacy of deference in questions of fact is thus even greater in transnational settings. However, even in cases where EU secondary law provides for an absolute and unconditional obligation to give effect to an administrative measure taken by the authorities of another Member State, it might still be possible for the courts of destination, under certain exceptional circumstances, to review incorrect factual statements made by the authorities of origin. The Court of Justice explored the possibility and limits of such a review in Altun, ${ }^{138}$ with regard to the application of social security schemes to posted workers. ${ }^{139}$ A Belgian construction undertaking had subcontracted the work at all its sites to Bulgarian undertakings that posted workers to Belgium. This was not declared to the Belgian authority responsible for the collection of social security contributions because the posted workers had certificates issued by the Bulgarian authority according to which they continued to be subject to the legislation of the Member State of origin. This required, in particular, that the undertaking habitually carried out significant activities in the territory of Bulgaria.

\footnotetext{
${ }^{134}$ Berlioz, Case C-682/15 at para. 77, which also refers to ECJ, Case C-420/98, W.N. v. Staatssecretaris van Financiën, EU:C:2000:209 (Apr. 13, 2000), para. 18, http://curia.europa.eu/juris/liste.jsf?language=en\&jur=C,T,F\&num=C-420/98\& $\mathrm{td}=\mathrm{ALL}$.

${ }^{135}$ Craig, supra note 23, at 444 .

${ }^{136}$ Hanns Peter Nehl, Judicial Review of Complex Socio-Economic, Technical, and Scientific Assessments in the European Union, in EU Executive Discretion AND the Limits of Law 158 (Joana Mendes ed., 2019).

${ }^{137}$ See, e.g., Commission v. France, Case C-188/84; ECJ, Case C-105/94, Ditta Angelo Celestini v. Saar-Sektkellerei Faber GmbH \& Co. KG, ECLI:EU:C:1997:277 (June 5, 1997), https://eur-lex.europa.eu/legal-content/EN/TXT/?uri=CELEX\% 3A61994CJ0105; ECJ, Case C-378/10, VALE Építési kft, ECLI:EU:C:2012:440 (July 12,2010), http://curia.europa.eu/juris/ liste.jsf?num $=\mathrm{C}-378 / 10$ \&language $=\mathrm{EN}$.

${ }^{138}$ ECJ, Case C-359/16, Criminal proceedings against Ömer Altun and Others, ECLI:EU:C:2018:63 (Feb. 6, 2018), http:// curia.europa.eu/juris/liste.jsf?language $=$ en\&td=ALL\&num $=$ C-359/16.

${ }^{139}$ Council Regulation 1408/71 of 14 June 1971, on the Application of Social Security Schemes, in the Version Amended and Updated by Council Regulation 118/97 of 2 December 1996, 1997 O.J. (L 28) 1.
} 
The Court of Justice ruled that, under the applicable secondary legislation, these certificates are binding on the authorities of destination, even in the case of a manifest error of assessment. ${ }^{140}$ Secondary EU law establishes a mandatory cooperation administrative procedure as a means of resolving disputes concerning the accuracy of documents drawn up by the authorities of origin. The Court of Justice stated that when the authorities of destination provide concrete evidence that suggests that those certificates were obtained fraudulently, it is the duty of the authorities of destination, by virtue of the principle of sincere cooperation, to review, in the light of that evidence, the grounds for the issue of those certificates and, where appropriate, to withdraw them. ${ }^{141}$ Interestingly enough, the Court also ruled that, in case the authorities of origin do not deal with this requirement, a court of the Member State of destination may disregard those certificatesthus depriving them of transnational legal effects-if it finds them fraudulent, and provided that the right to a fair trial is respected. ${ }^{142}$ Altun shows, therefore, that even in areas of legislative mutual recognition, where authorities of destination must defer to factual statements made by the authorities of origin, courts of the Member State of destination may disregard them, provided that certain conditions are met, both of substantive - fraudulent content - and procedural nature - related to administrative cooperation and judicial procedures.

\section{Discretion}

Finally, the standard of review of discretion raises similar issues. When mutual recognition is somehow conditioned or qualified, and therefore is not an absolute and passive mutual recognition arrangement, the courts of destination might have to review administrative discretion. Two different perspectives must be distinguished here. First, the implementation of exceptions to mutual recognition by the administrative authorities of the Member State of destination will often involve the use of discretionary powers. This will be the case, for instance, when a decision on tolerated risks leads to impeding commercialization in the Member State of destination of goods that are legally produced and marketed in the Member State of origin. ${ }^{143}$ Review of discretion will here unfold according to the doctrines and techniques that are applied in purely internal situations. Despite both the Court of Justice and the General Court having developed a rich doctrine on judicial review of discretionary decisions of EU authorities, EU law does not impose a homogeneous model of judicial review of discretion upon domestic courts. ${ }^{144}$ However, because Articles 19 TEU and 47 of the Charter do require judicial control to be effective, from both the subjective and objective perspective, it remains to be explored whether and to what extent this imposes certain limitations on domestic judicial deference.

Second, decisions taken by the authorities of the Member State of origin might also involve the use of discretionary powers. The question is, therefore, to what extent courts of the Member State of destination must defer to them. Interestingly enough, the relevant criteria push here in somewhat opposite directions. On the one hand, the epistemological objection to judicial review of discretion is even louder in favoring deference when the deciding authority and the controlling court belong to different jurisdictions. ${ }^{145}$ On the other hand, deference to discretionary decisions made by the executive can also be grounded on separation of powers considerations. ${ }^{146}$ Insofar as

\footnotetext{
${ }^{140}$ Altun, Case C-359/16 at para. 46.

${ }^{141} I d$. at para. 54 .

${ }^{142} I d$. at para. 61.

${ }^{143}$ ECJ, Case C-174/82, Criminal proceedings against Sandoz BV, ECLI:EU:C:1983:2013 (July 14, 1983), para. 16, http:// curia.europa.eu/juris/liste.jsf?language $=$ en,T,F\&num $=174 / 82$.

${ }^{144}$ Herwig C.H. Hofmann, Gerard C. Rowe \& Alexander H. Turk, Administrative law and Policy of the EUROPEAN UNION 505-06 (2011).

${ }^{145}$ Vermeule, supra note 123; Paul Horwitz, Three Faces of Deference, 83 Notre Dame L. Rev. $1079-85$ (2008).

${ }^{146}$ Horwitz, supra 139, at 1085-94; Bernardo Mattarella, Law and Discretion: A Public Law Perspective on the EU, in EU Executive Discretion AND the Limits of Law 38 (Joana Mendes ed., 2019).
} 
the former involve expressing political preferences, it makes sense that they remain in the hands of governmental and administrative bodies, which are subject to their own legitimacy processes. The reduction of judicial accountability of executive discretion would, thus, be compensated by an increased political accountability. In other words, the source of legitimacy would shift from the rule of law to democracy. In a multijurisdictional context, however, democratic control of the authorities of origin cannot be performed within the institutional system of the Member State of destination, nor will the institutional system of the Member State of origin effectively control the transnational effects that discretional measures may have in other Member States. Therefore, in transnational settings, such as those brought about by mutual recognition obligations, judicial and political accountability are less substitutes than in purely national situations. In sum, this other rationale would not support a more deferential approach from the courts of the Member State of destination to foreign discretionary decisions.

In order to solve this constitutional conundrum, a distinction must be made between discretionary decisions taken by the authorities of origin, depending on the discretionary power being granted by the law of origin or by EU law. In the first scenario, the abovementioned systematic argument would be crucial in terms of providing legitimacy to judicial deference towards foreign administrative discretion. As has been said regarding questions of law, from the perspective of the courts of destination, the law of origin is composed of both rules and single-case decisions that frequently involve the use of discretionary powers. Whenever administrative and judicial authorities of destination are bound to give effect to foreign law, the mutual recognition obligation reaches to discretionary decisions taken by the authorities of origin. This is readily apparent in the case of giving effect to administrative rules, which have a discretionary nature, and the same is true regarding single-case administrative decisions, such as those granting or revoking an administrative license, that under domestic law, may have discretional nature.

Yet in the second scenario this must be somewhat qualified by virtue of Article 47 of the Charter. In Berlioz, the Court of Justice dealt with this question in a horizontal administrative cooperation case. Articles 1(1) and 5 of Directive 2011/16/EU authorizes national tax administrations to request other national authorities to exchange information that is "foreseeably relevant" for the requesting administration in the light of the provisions of its own domestic legislation. ${ }^{147}$ Only if the requested information is foreseeably relevant will the requested authority be obliged to cooperate. ${ }^{148}$ The Court stressed that it is for the requesting authority to assess the foreseeable relevance of the information for that investigation in view of the circumstances of the case, the progress made in the proceedings, and the previous exhaustion of other usual sources of information. ${ }^{149}$ Because the "requesting authority has a discretion in that regard," 150 the requested authority "must, in principle, trust the requesting authority and assume," not only, as we have seen, that the request for information it has been sent complies with the domestic law of the requesting authority, but also that it "is necessary for the purposes of its investigation." For this very reason, "the requested authority cannot substitute its own assessment of the possible usefulness of the information sought for that of the requesting authority." 151

However, in Berlioz, neither the Court of Justice, nor the relevant EU secondary law measure, granted the requesting authorities unfettered discretion regarding the assessment of whether a certain piece of information is foreseeably relevant. The Court stressed that the Directive does not let Member States "engage in fishing expeditions," nor does it let them request information that is unlikely to be relevant to the tax affairs of a given taxpayer. On the contrary, there must be a

\footnotetext{
${ }^{147}$ Council Directive 2011/16/EU of 15 February 2011 on Administrative Cooperation in the Field of Taxation, 2011 O.J. (L 64) 1.

${ }^{148}$ Berlioz, Case C-682/15 at para. 63.

${ }^{149} I d$. at para. 70 .

${ }^{150} I d$. at para. 71.

${ }^{151} I d$. at para. 77.
} 
reasonable possibility that the requested information will be relevant. ${ }^{152}$ Consequently, in spite of the requesting authority's discretion, "it cannot request information that is of no relevance to the investigation concerned," 153 and "must provide an adequate statement of reasons explaining the purpose of the information." 154 Interestingly enough, the Court makes clear that the requested authorities will be entitled to control the assessment of the requesting authorities, and that this review is not limited "to a brief and formal verification ... but must also enable that authority to satisfy itself that the information sought is not devoid of any foreseeable relevance." 155

As for the judicial assessment carried out by the courts of destination, the judgment makes two important points. First, that judicial examination of the information request, in spite of its discretionary nature, is mandatory by virtue of the right to effective judicial protection enshrined in Article 47 of the Charter, ${ }^{156}$ and second, that "the limits that apply in respect of the requested authority's review are equally applicable to reviews carried out by the courts." 157 Accordingly, courts may review the use of discretion by the requesting authorities, but only in order to "verify that the information order is based on a sufficiently reasoned request by the requesting authority concerning information that is not - manifestly-devoid of any foreseeable relevance."158

The Court provides, therefore, for a very lenient and deferential standard of review of foreign discretionary decisions. However, the difference with the first scenario is that, here, there might be some judicial consideration of the foreign discretionary measure. This doctrine is a major development in the construction of the fundamental right to effective judicial protection in the European administrative space. And it could be applied by analogy to other transnational settings, such as those brought about by mutual recognition arrangements, provided that EU law is not only the source of the mutual recognition obligation, but also of the discretionary power used by the authorities of origin. In Berlioz, the Court of Justice allows judicial assessment of foreign discretionary measures insofar as discretion and its limits have an EU law basis. This might be the case in those mutual recognition settings where EU secondary law itself provides for a more or less detailed regulatory framework and confers a discretionary power upon the authorities of origin. On the contrary, the analogy with Berlioz would be inapplicable in those other cases where the discretionary power is granted by the domestic legal order of the authorities of origin, and EU law simply gives way to it through an exception to the mutual recognition obligation. Here, required deference to foreign administrative discretion is higher than in Berlioz, and therefore the courts of the Member State of destination should not even apply its lenient standard of review.

\section{Conclusions}

This Article has focused on an underexplored question in EU law: Namely, what the gaps are in effective judicial protection that typically arise in horizontal interactions that are brought about by the application of a mutual recognition obligation imposed by EU law. The fact that the authorities of the Member State of destination must give effect to foreign rules or acts, which thus gain transnational effects, gives rise to the emergence of a set of problems in terms of carrying out judicial review.

The first problem is that procedural law of the Member States may impede or make it excessively difficult for affected individuals or firms to challenge rules or acts of the Member State of origin before a court. According to the principle of separation, they can only seek annulment before the courts of the Member State of origin. Access to them may, however, be precluded

\footnotetext{
${ }^{152} I d$. at para. 67.

${ }^{153}$ Berlioz, Case C-682/15 at para. 71.

${ }^{154} I d$. at para. 80.

${ }^{155} \mathrm{Id}$. at para. 82 .

${ }^{156} I d$. at para. 84 .

${ }^{157} I d$. at para. 85 .

${ }^{158} I d$. at para. 86 .
} 
by widespread restrictions of the reviewability of acts laid down in the domestic procedural law of the Member States. This gap has a distinctive constitutional dimension because it has an effect on a building block of the fundamental right to effective judicial protection-namely, the rule that forbids abstract categories of acts being immune to judicial review-that behaves as an indefeasible norm.

The solution is to admit that, when reviewing the decision taken by the authorities of the Member State of destination regarding an individual or firm whose rights or obligations might be affected by a transnational measure, the courts of destination will have jurisdiction to assess whether they are required to give them effect by virtue of a mutual recognition obligation. Procedurally, this is admissible as long as actions are not brought against the rule or act of origin, but against the decision of the authorities of the Member State of destination whereby they recognize, reject, or qualify the transnational effects of the former. Courts of destination have no jurisdiction to review the validity of rules and acts of origin, but they certainly have jurisdiction to decide on their transnational applicability. Finally, it has been suggested here that this conclusion can be grounded on the application by analogy of the doctrine established in Berlioz by the Court of Justice. ${ }^{159}$

A second difficulty relates to the law that must be taken into account by the courts of the Member State of destination when it comes to reviewing administrative acts that give-or refuse to give-effect to a measure adopted by another Member State. This Article has dealt with the questions of whether and to what extent the courts of destination will have to interpret and apply their own domestic legal order, the law of the EU, and the law of origin. Different groups of cases have been mapped in this respect. As for the law of origin, the problem of how the courts of destination can cope with uncertainty regarding its content has also been tackled. The possibilities offered by recent developments in the case law of the Court of Justice on the scope and limits of the principle of sincere cooperation, under Article 4(3) TEU, should be further explored. In particular, the Article reasons that the doctrine established in Eurobolt can also be applied by analogy to horizontal cooperation between the courts of destination and the non-judicial authorities of origin. ${ }^{160}$

The third difficulty relates to the standards of review that the courts of destination must apply to statements made by the authorities of origin regarding questions of law, fact, and discretion. Whereas the greatest deference is due regarding points of law, ${ }^{161}$ as well as discretionary decisions regulated by domestic legislation, ${ }^{162}$ the courts of destination must carry out-an admittedly lowintensity-judicial review in two other scenarios. On the one hand, when it comes to examining fraudulent factual assessments, the application by analogy of the Altun doctrine can lead to the courts of destination not recognizing transnational effects to foreign certificates. ${ }^{163}$ On the other hand, Berlioz also makes it possible for the courts of destination to verify whether a discretionary power granted by EU law has been reasonably used by the authorities of origin. ${ }^{164}$

Limitations on the law that can be taken into account by the courts of the Member State of destination, as well as rules and practices that lead to the application of deferential standards of review to foreign measures, can diminish the intensity of judicial review. As long as they impede the courts from considering questions that might be relevant to the case before them, these legal norms and doctrines must be conceived of as restrictions of the right to comprehensive judicial review, which is a dimension of effective judicial protection where the fundamental right functions as an optimization mandate. Consequently, restrictions like these can be admissible insofar as they

\footnotetext{
${ }^{159}$ See supra Section C(I)(3).

${ }^{160}$ See supra Section C(II)(3).

${ }^{161}$ See supra Section C(III)(1).

${ }^{162}$ See supra Section C(III)(3).

${ }^{163}$ See supra Section C(III)(2).

${ }^{164}$ See supra Section C(III)(3).
} 
satisfy the requirements laid down by Article 52(1) of the Charter. In particular, more or less deferential standards of review of law, fact and, discretion can be seen as necessary measures that genuinely meet objectives of general interest recognized by the EU-such as the effectiveness of mutual recognition arrangements, or the need to protect the rights and freedoms of othersnamely, the fundamental freedoms and other rights of transnational undertakings and individuals from other Member States, whose effectiveness is enhanced by them. 